\title{
Oxygen atom transfer in the oxidation of dimethyl sulfoxide by
}

\section{oxoammonium cations}

Vasily D. Sen'1*, Valery A. Golubev ${ }^{1}$, Gennadii V. Shilov ${ }^{1}$, Alexander V. Chernyak ${ }^{1}$, Vladimir A. Kurmaz ${ }^{1}$, and Victor B. Luzhkov ${ }^{1,2}$

${ }^{1}$ Institute of Problems of Chemical Physics, Russian Academy of Sciences, Chernogolovka, 142432, Russian Federation, ${ }^{2}$ Department of Fundamental Physico-Chemical Engineering, Lomonosov Moscow State University, Moscow 119991, Russia

* $\underline{\text { senvd@icp.ac.ru }}$

\section{Table of Contents}

1. NMR spectra

2. IR spectra

3. Mass spectra .524

4. X-ray crystal data of $\mathbf{1 f}$ and $\mathbf{2 f}$ . $\mathrm{S} 27$

5. Equilibrium of charge transfer complex formation for $\mathbf{1 a}^{+} \mathrm{Cl}^{-}$in $\mathrm{MeCN}$...S31 


\section{NMR spectra}

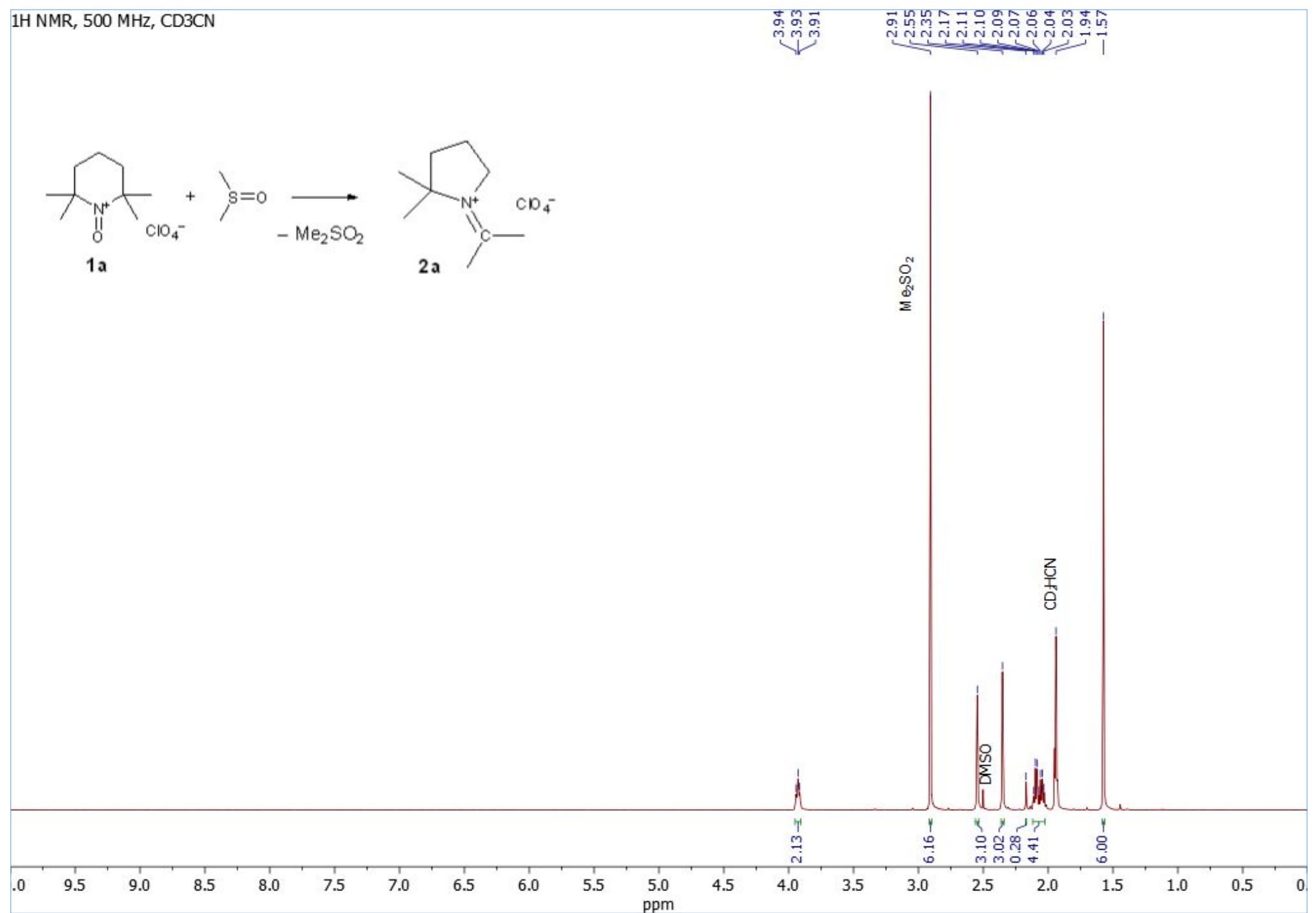

Figure S1.1. 1H NMR spectrum of reaction mixture of salt $1 \mathrm{a}(25.3 \mathrm{mg}, 0.099 \mathrm{mmol})$ and DMSO ( $8.0 \mathrm{mg}, 0.102 \mathrm{mmol}) \mathrm{in} 0.6 \mathrm{ml}$ of CD $\mathrm{CN}$, reaction time $1 \mathrm{~h}$. 


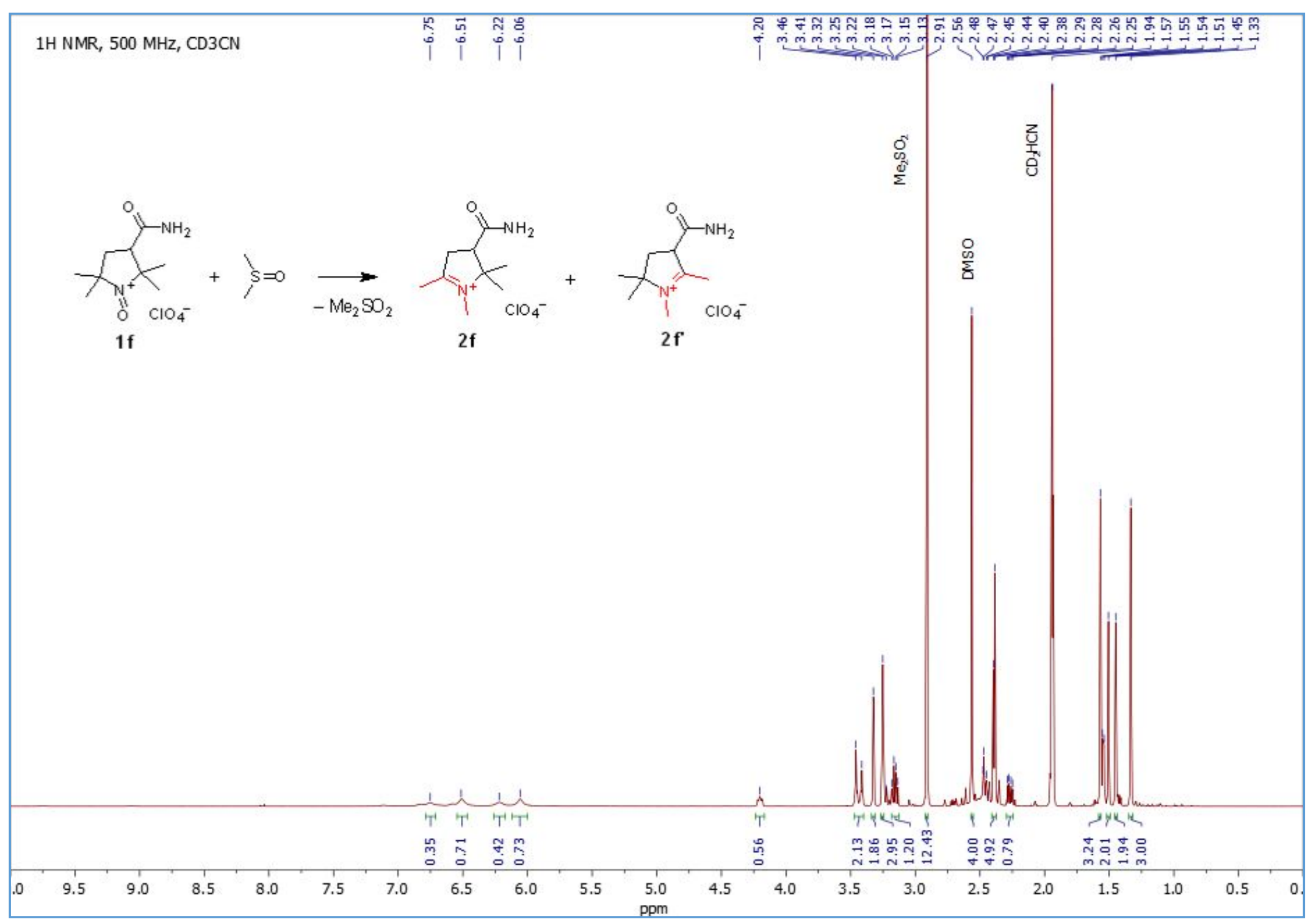

Figure S1.2. 1H NMR spectrum of reaction mixture of salt $1 \mathbf{f}(21.8 \mathrm{mg}, 0.076 \mathrm{mmol})$ and DMSO $(8.0 \mathrm{mg}, 0.10 \mathrm{mmol})$ in $0.7 \mathrm{ml}$ of CD $\mathrm{CN}_{3}$, reaction time $1 \mathrm{~h}$. The ratio of isomers $\mathbf{2 f}: \mathbf{2 \mathbf { f } ^ { \prime }}=\sim 60: 40$ was determined from integrals of the signals at 1.33 and $1.45 \mathrm{ppm}$. 


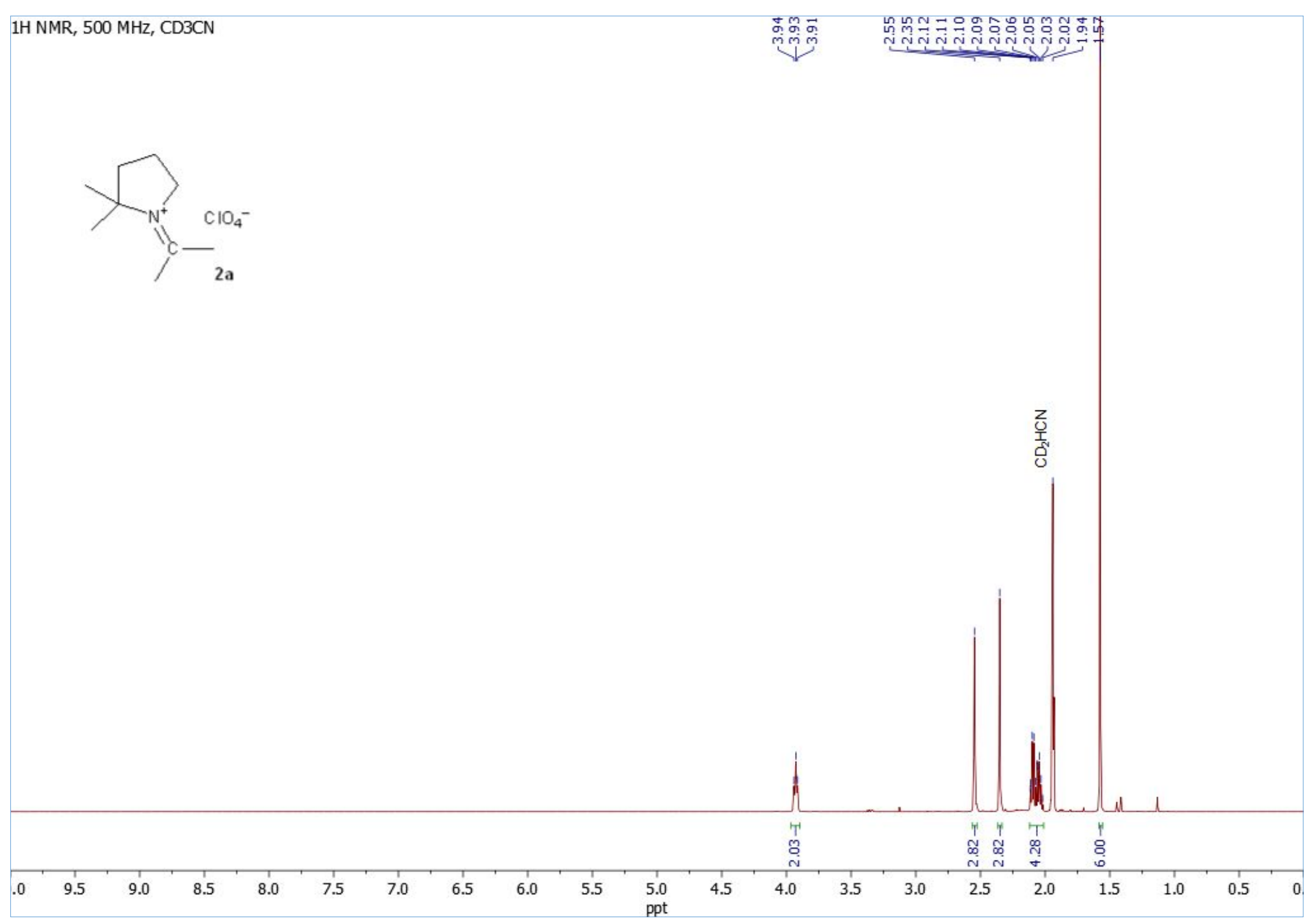

Figure S1.3. 1H NMR spectrum of iminium salt $\mathbf{2 a}$ in $\mathrm{CD}_{3} \mathrm{CN}$. 


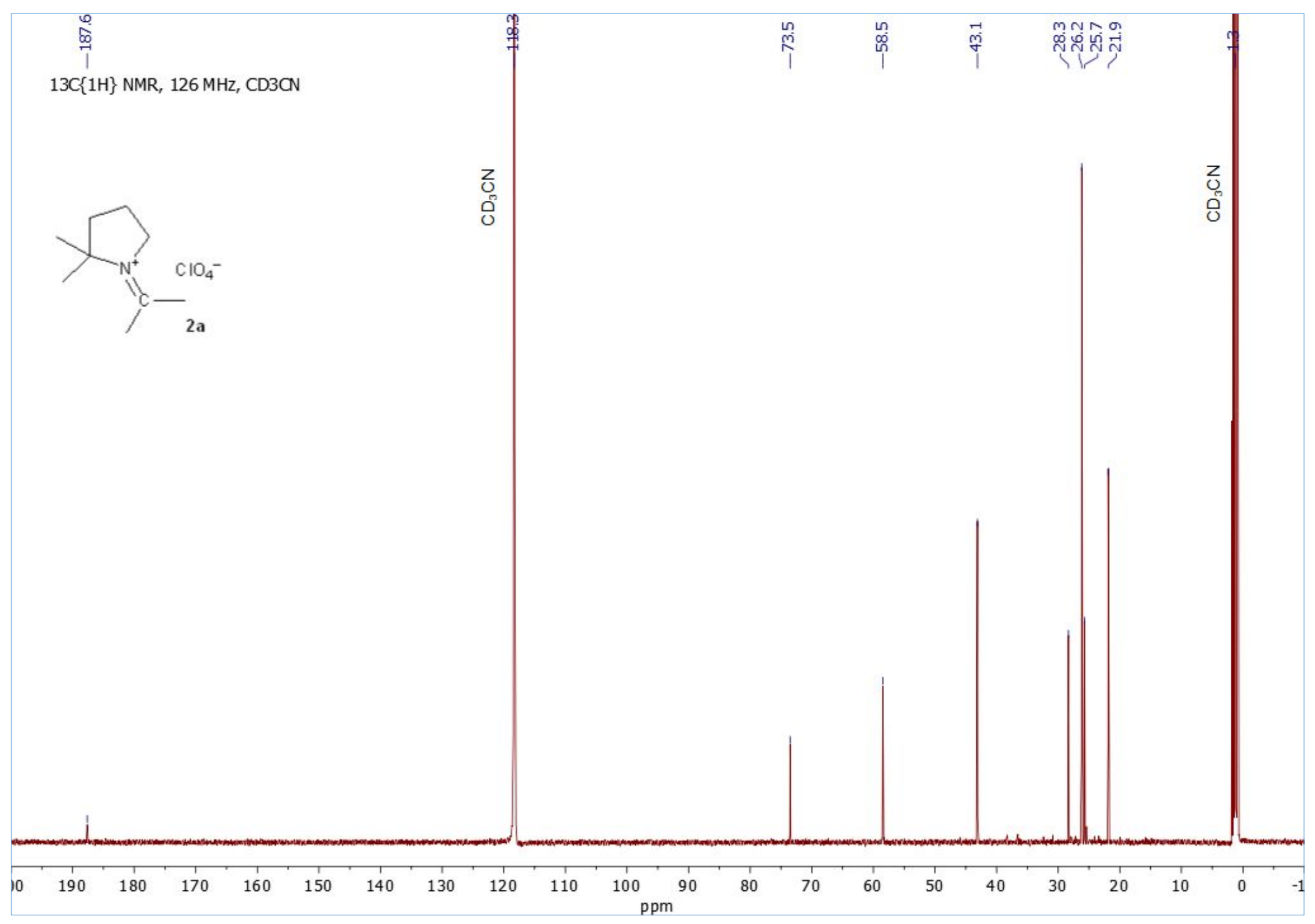

Figure S1.4. 13C $\{1 \mathrm{H}\}$ NMR spectrum of iminium salt $\mathbf{2 a}$ in $\mathrm{CD}_{3} \mathrm{CN}$. 


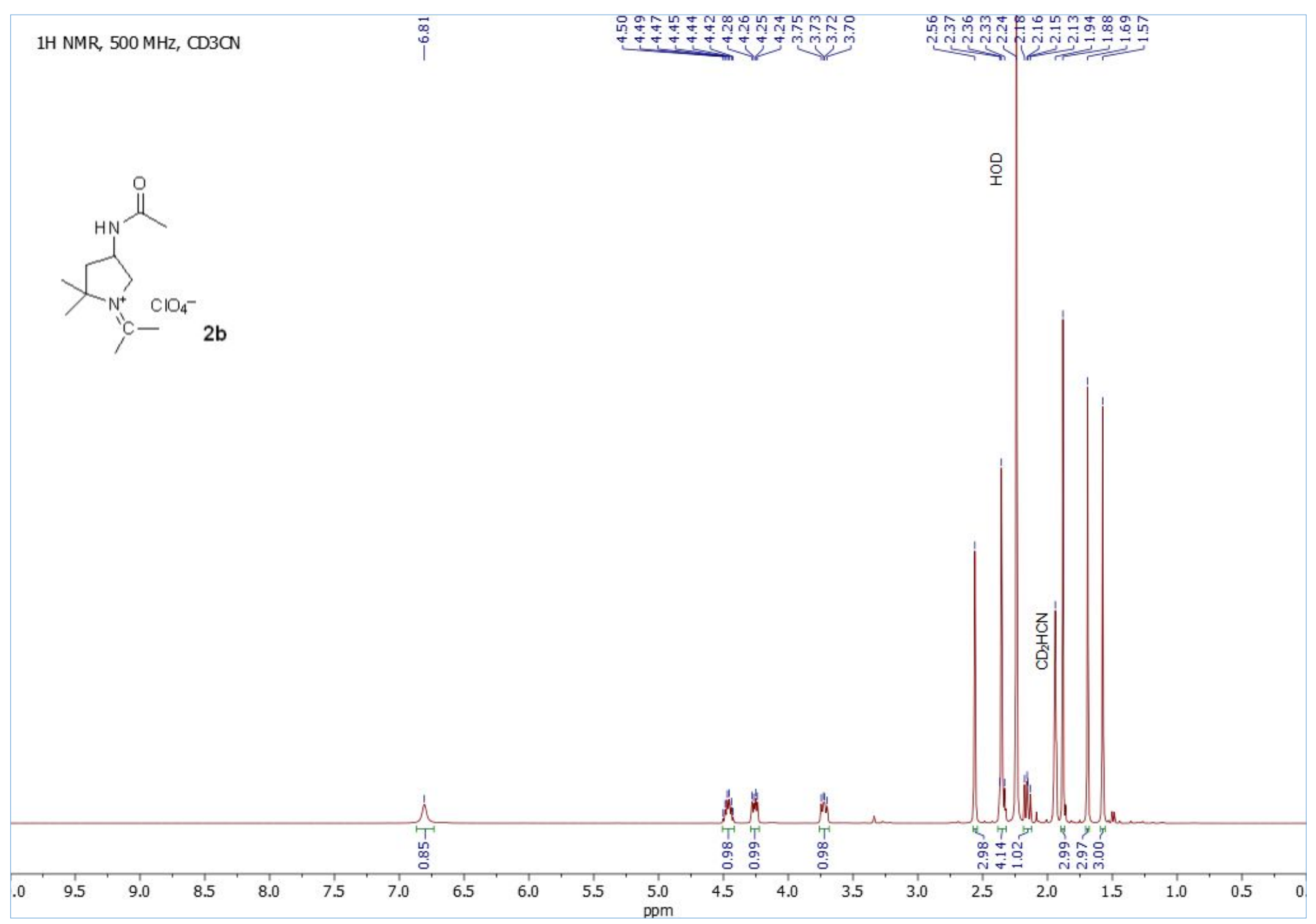

Figure S1.5. 1H NMR spectrum of iminium salt $\mathbf{2 b}$ in $\mathrm{CD}_{3} \mathrm{CN}$. 


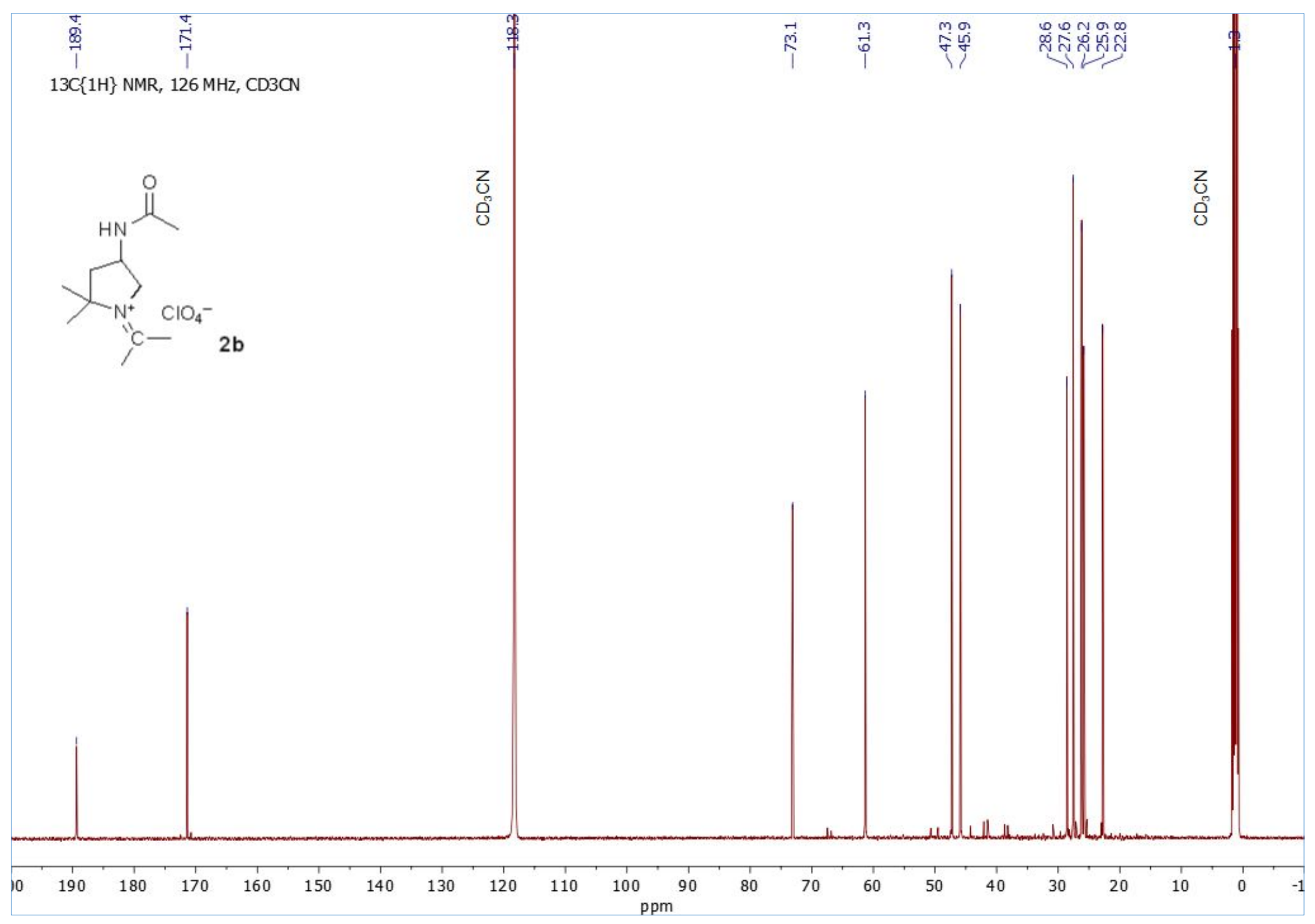

Figure S1.6. $13 \mathrm{C}\{1 \mathrm{H}\}$ NMR spectrum of iminium salt $\mathbf{2 b}$ in $\mathrm{CD}_{3} \mathrm{CN}$. 


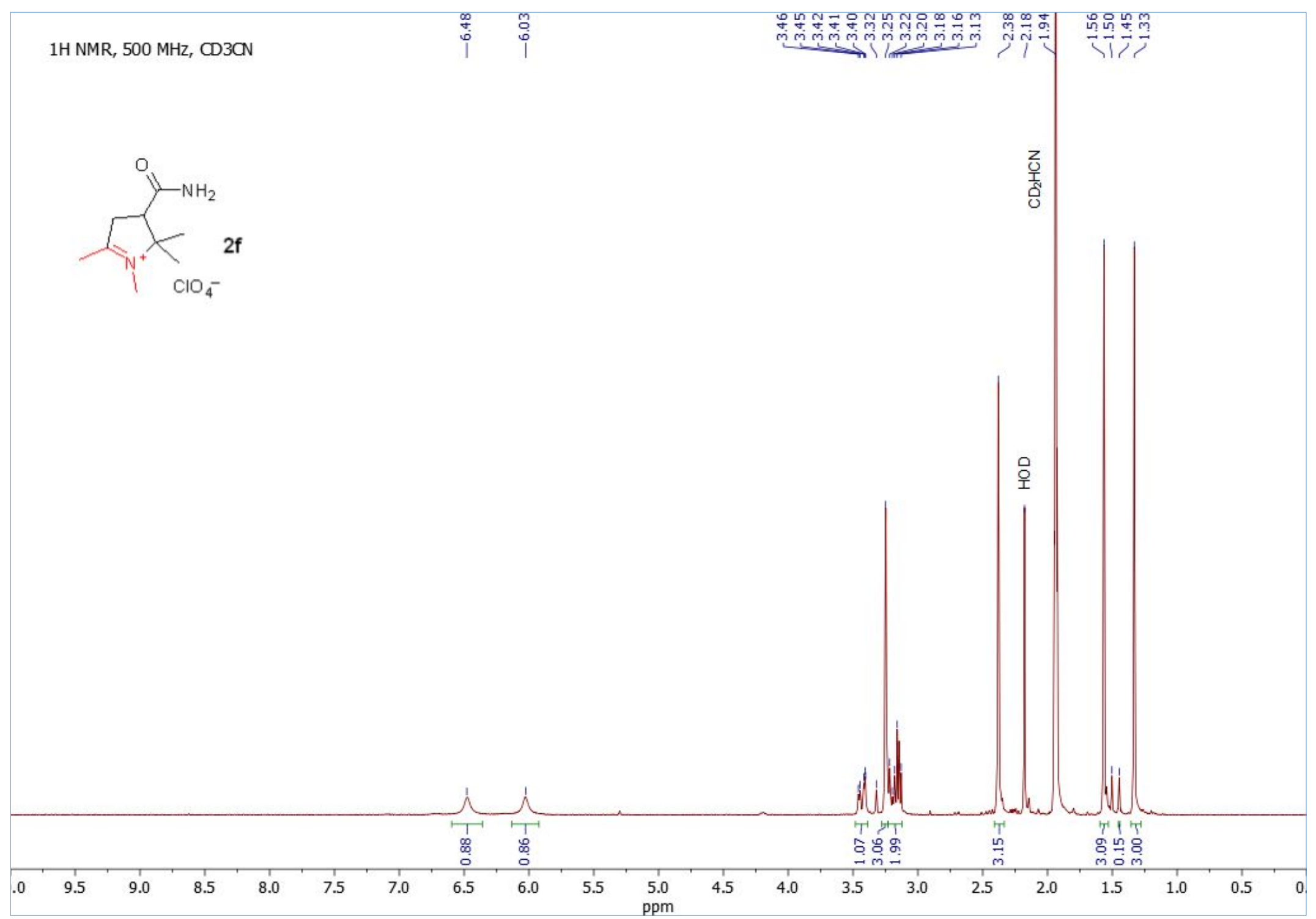

Figure S1.7. 1H NMR spectrum of iminium salt $\mathbf{2} \mathbf{f}$ in $\mathrm{CD}_{3} \mathrm{CN}$. As follows from integrals of the signals at 1.33 and $1.45 \mathrm{ppm}$ the sample contains $\sim 5 \%$ of isomer $\mathbf{2} \mathbf{f}^{\prime}$. 


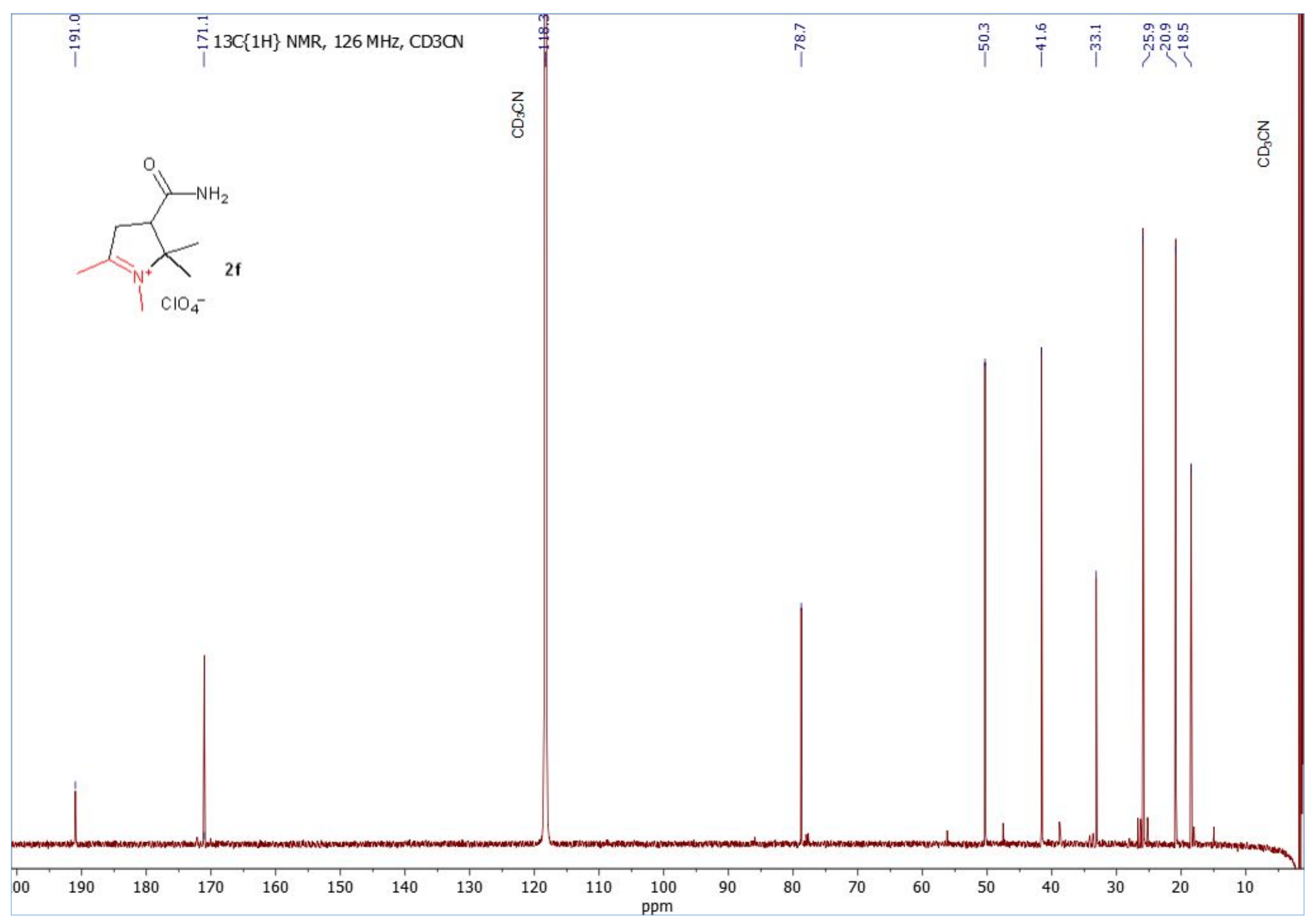

Figure $\mathrm{S} 1.8 .13 \mathrm{C}\{1 \mathrm{H}\}$ spectrum of iminium salt $\mathbf{2} \mathbf{f}$ in $\mathrm{CD}_{3} \mathrm{CN}$. 


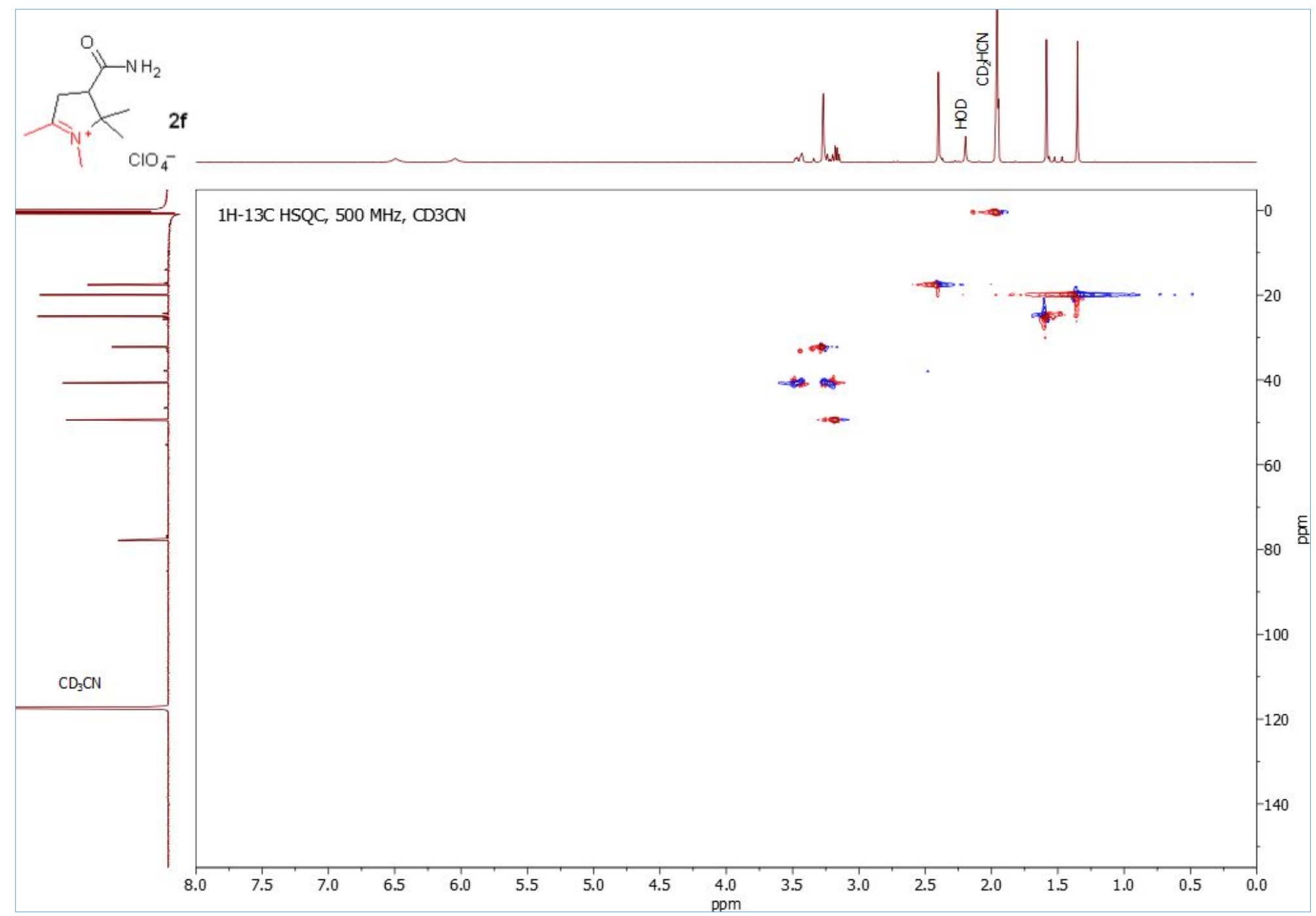

Figure S1.9. 1H-13C HSQC spectrum of iminium salt $\mathbf{2} \mathbf{f}$ in $\mathrm{CD}_{3} \mathrm{CN}$. 


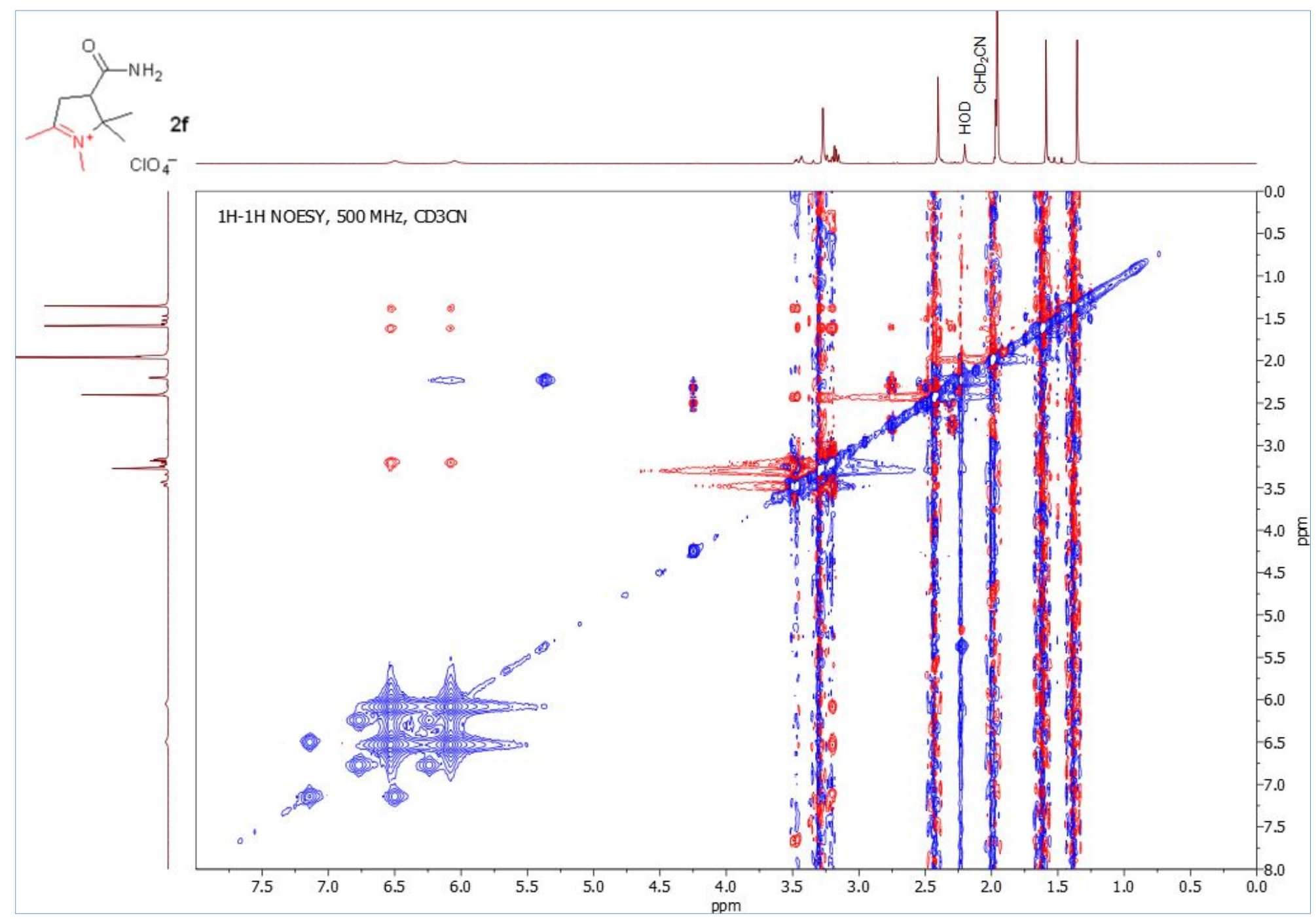

Figure S1.10. 1H-1H NOESY spectrum of iminium salt $\mathbf{2} \mathbf{f}$ in $\mathrm{CD}_{3} \mathrm{CN}$. 


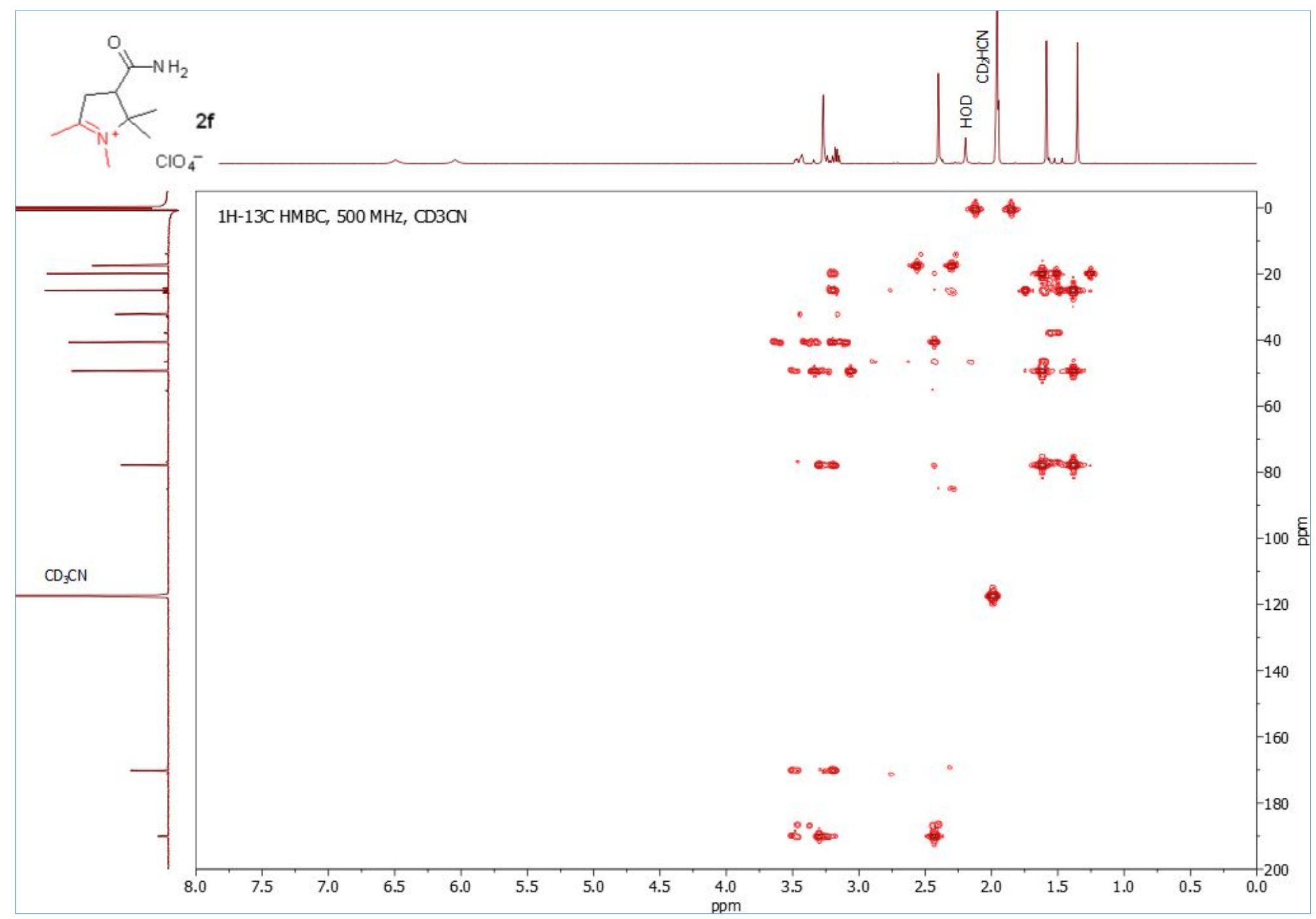

Figure S1.11. 13C-1H HMBC spectrum of iminium salt $2 \mathbf{f}$ in $\mathrm{CD}_{3} \mathrm{CN}$. 


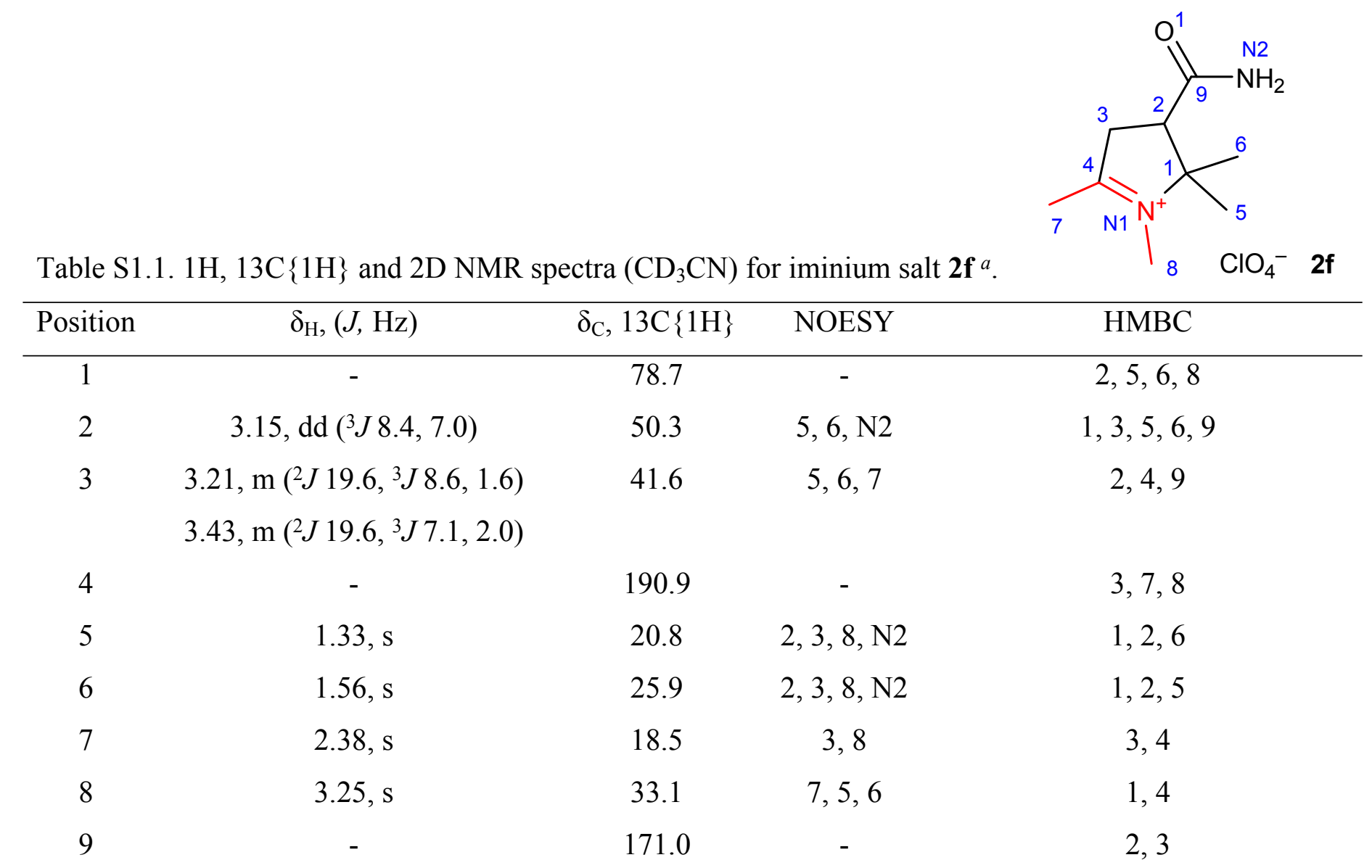

${ }^{a}$ The numbering of atoms in the table and in the crystal structure of salt $\mathbf{2 f}$ is the same (SI, Figure S4.2). In the main text, locants for atoms of $\mathbf{2 f}$ correspond to systematic name. 


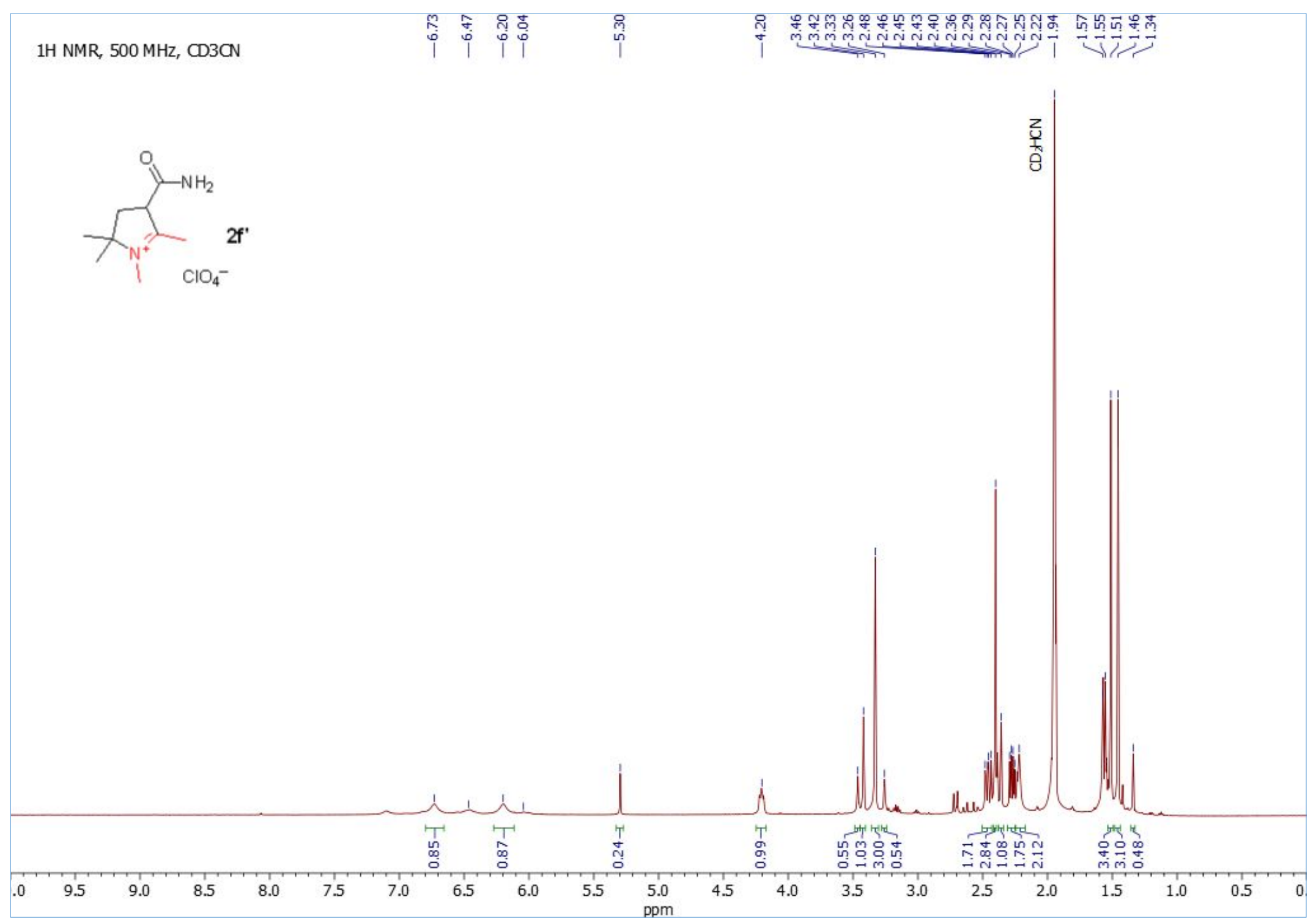

Figure S1.12. 1H NMR spectrum of iminium salt $\mathbf{2} \mathbf{f}^{\prime}$ in $\mathrm{CD}_{3} \mathrm{CN}$. From the ratio of the integrals of the signals at 1.34 and 1.46 ppm follows that the sample of $\mathbf{2} \mathbf{f}^{\prime}$ contains $\sim 15 \%$ of the isomer $\mathbf{2 f}$. 


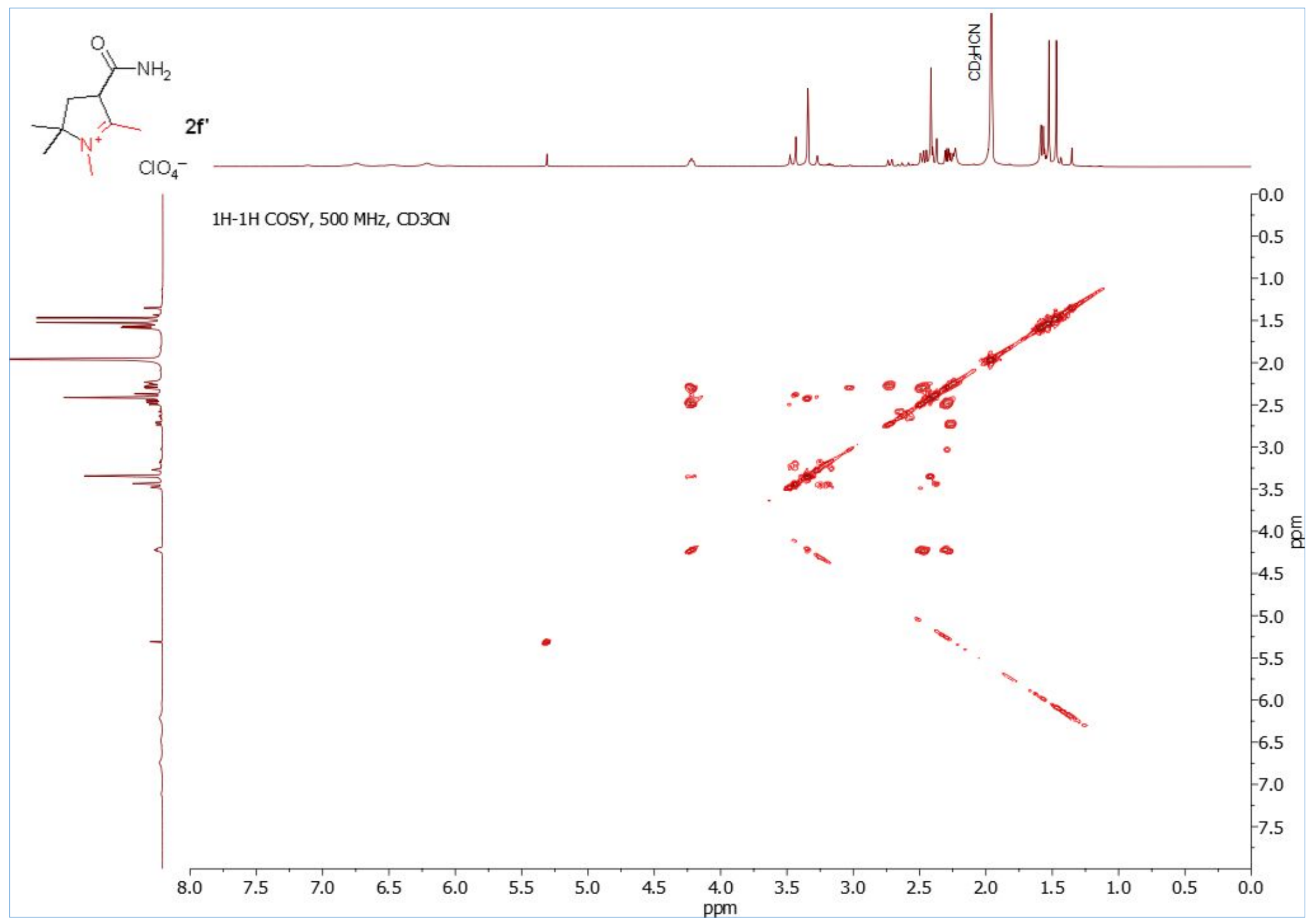

Figure S1.13. 1H-1H COSY spectrum of iminium salt $\mathbf{2} \mathbf{f}^{\prime}$ in $\mathrm{CD}_{3} \mathrm{CN}$. The sample contains $\sim 15 \%$ of the isomer $\mathbf{2 f}$. 


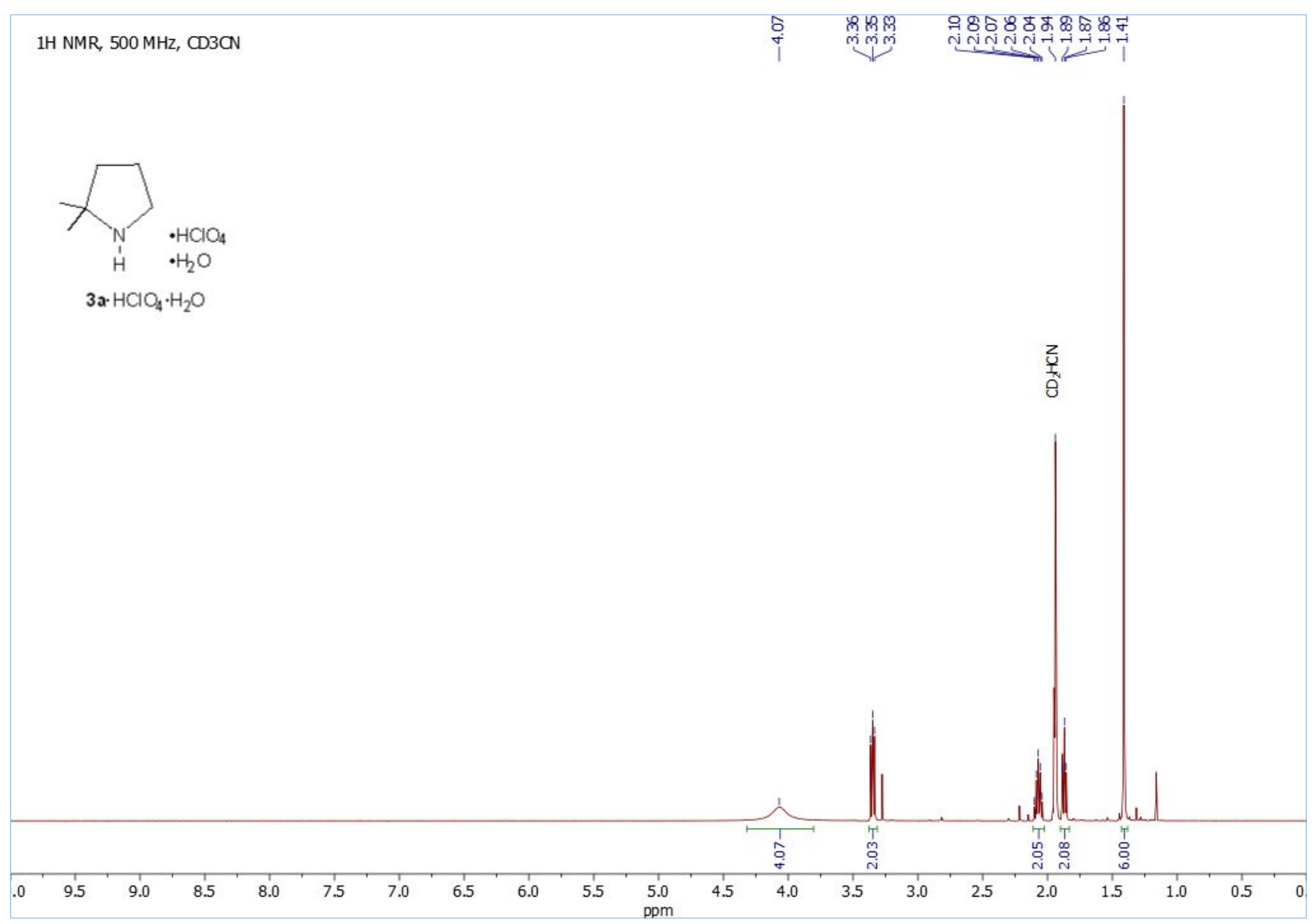

Figure S1.14. 1H NMR spectrum of pyrrolidinium salt $\mathbf{3 a} \cdot \mathrm{HCl} \cdot \mathrm{H}_{2} \mathrm{O}$ in $\mathrm{CD}_{3} \mathrm{CN}$. 


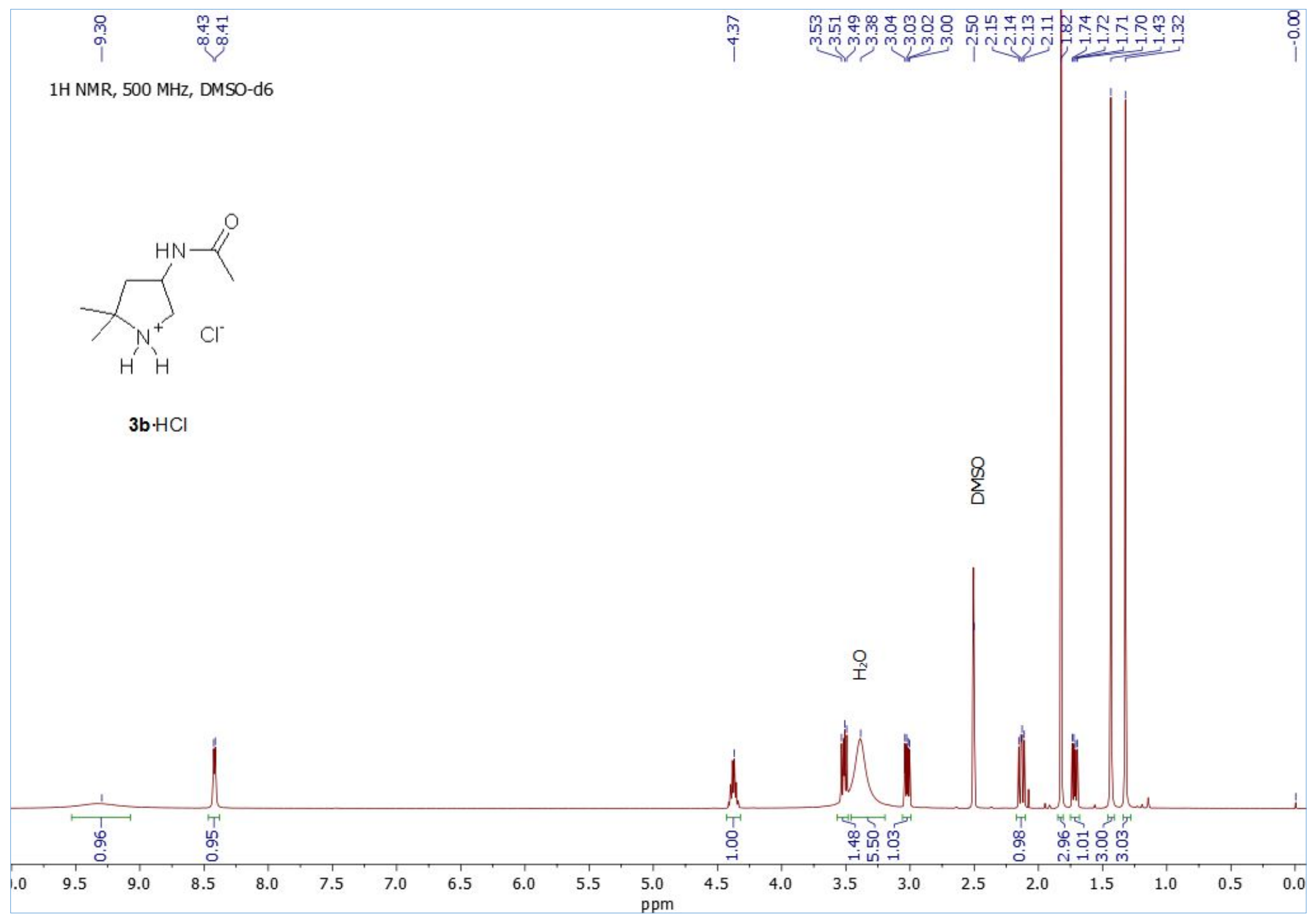

Figure S1.15. 1H NMR spectrum of pyrrolidine $\mathbf{3 b} \cdot \mathrm{HCl}$ in DMSO-d6. 


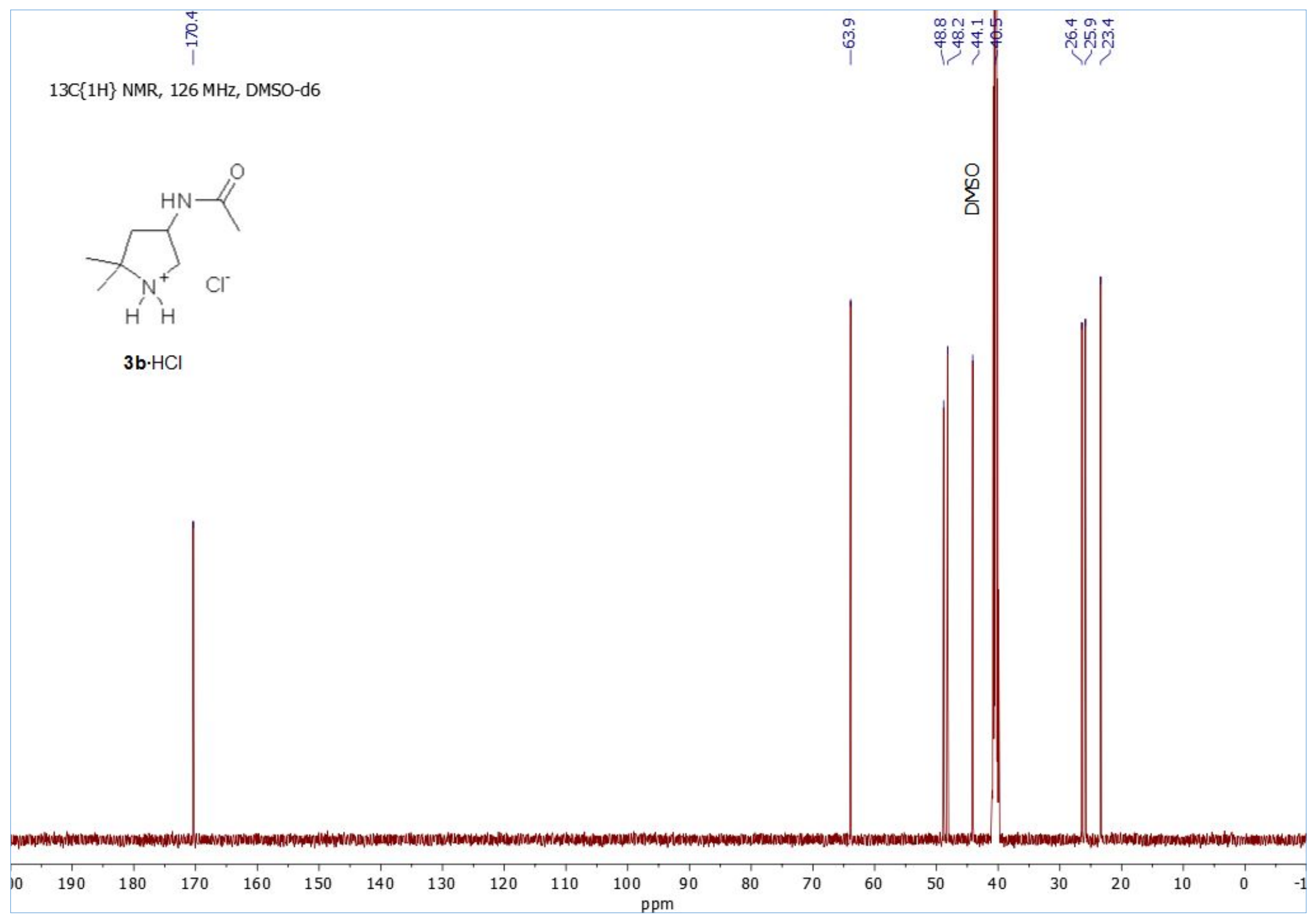

Figure $\mathrm{S} 1.16 .13 \mathrm{C}\{1 \mathrm{H}\}$ spectrum of iminium salt $\mathbf{3 b} \cdot \mathrm{HCl}$ in DMSO-d6. 


\section{IR spectra}

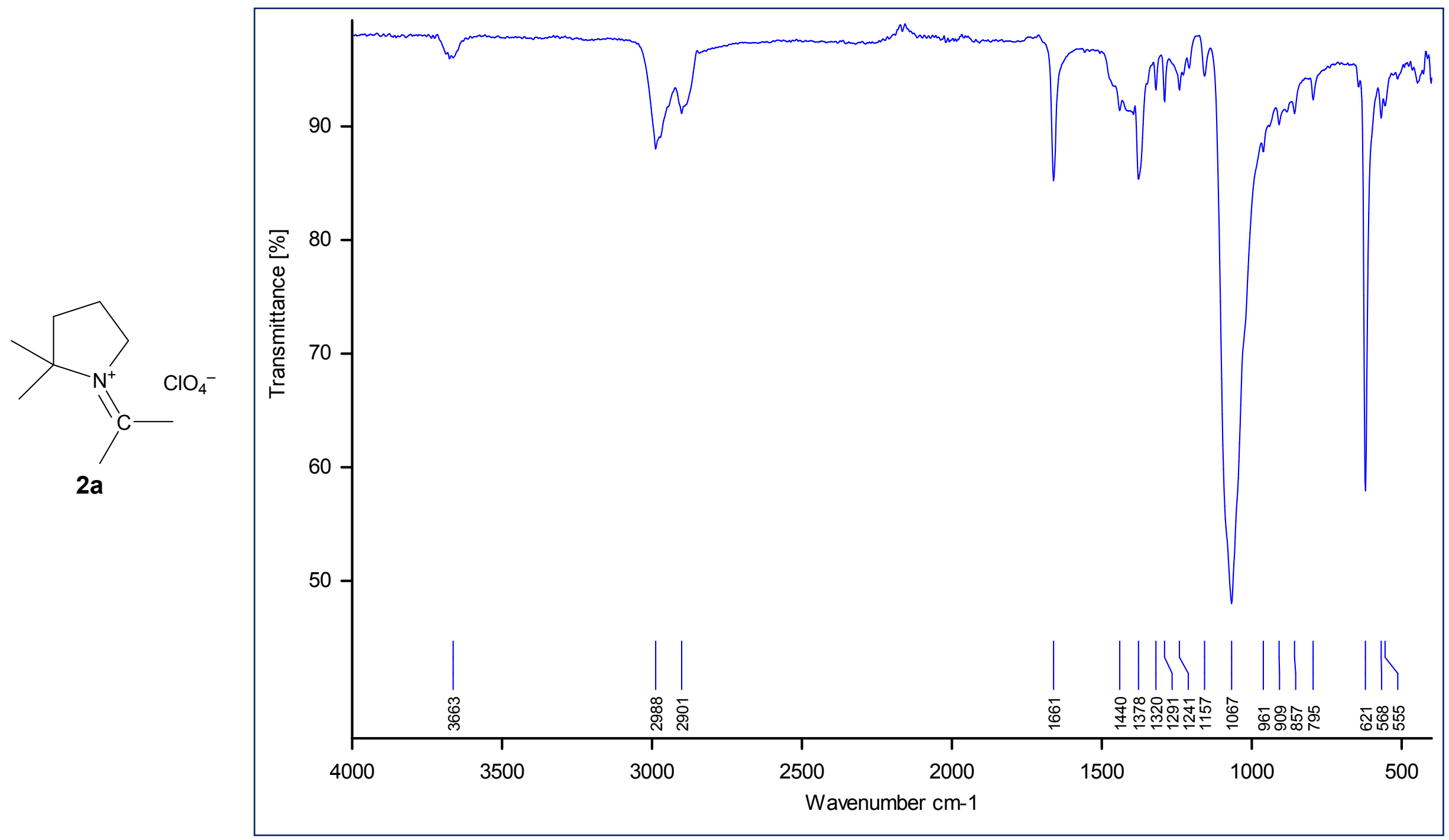

Figure S2.1. IR spectrum of iminium salt 2a. 


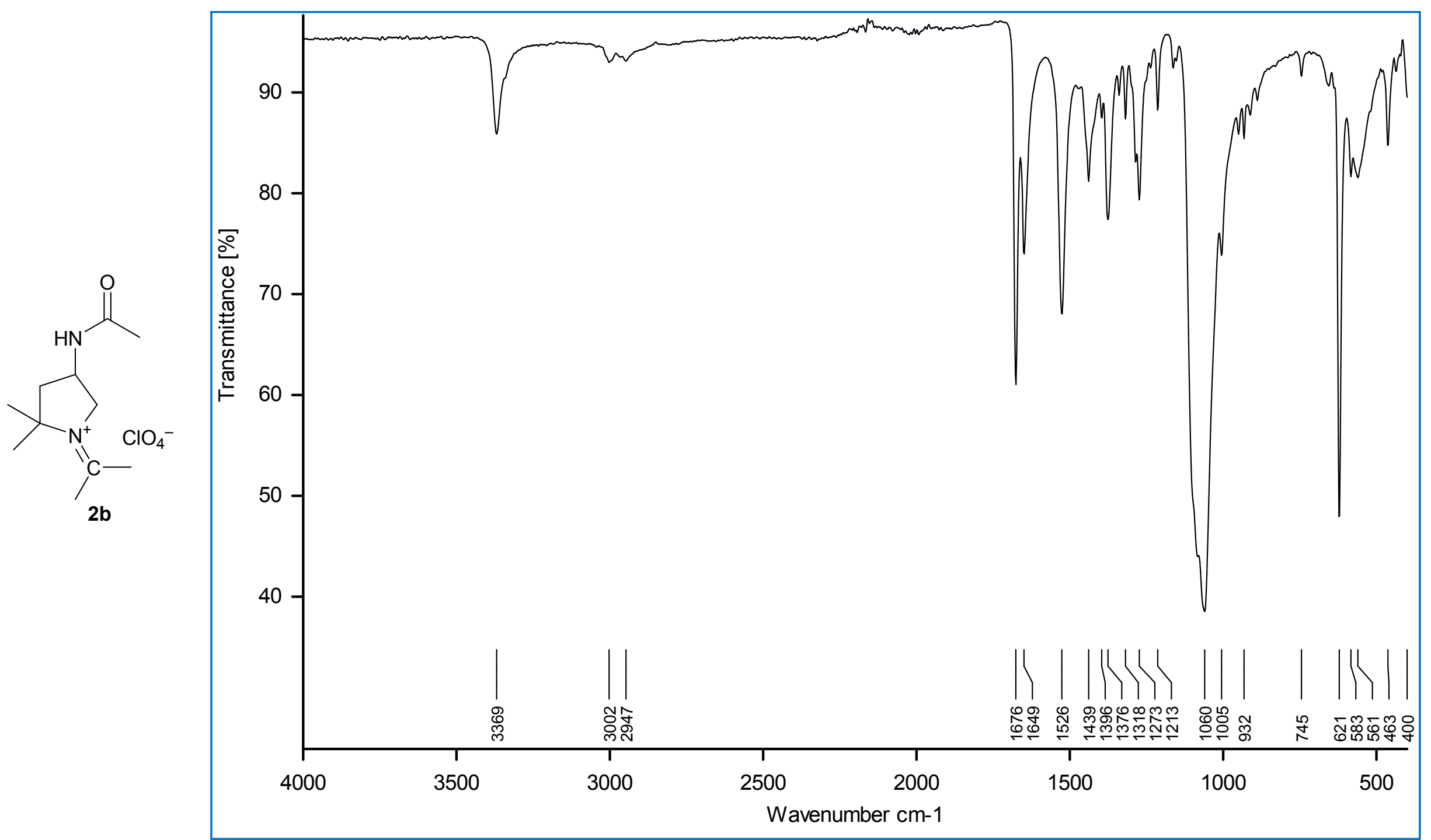

Figure S2.2. IR spectrum of iminium salt $\mathbf{2 b}$. 


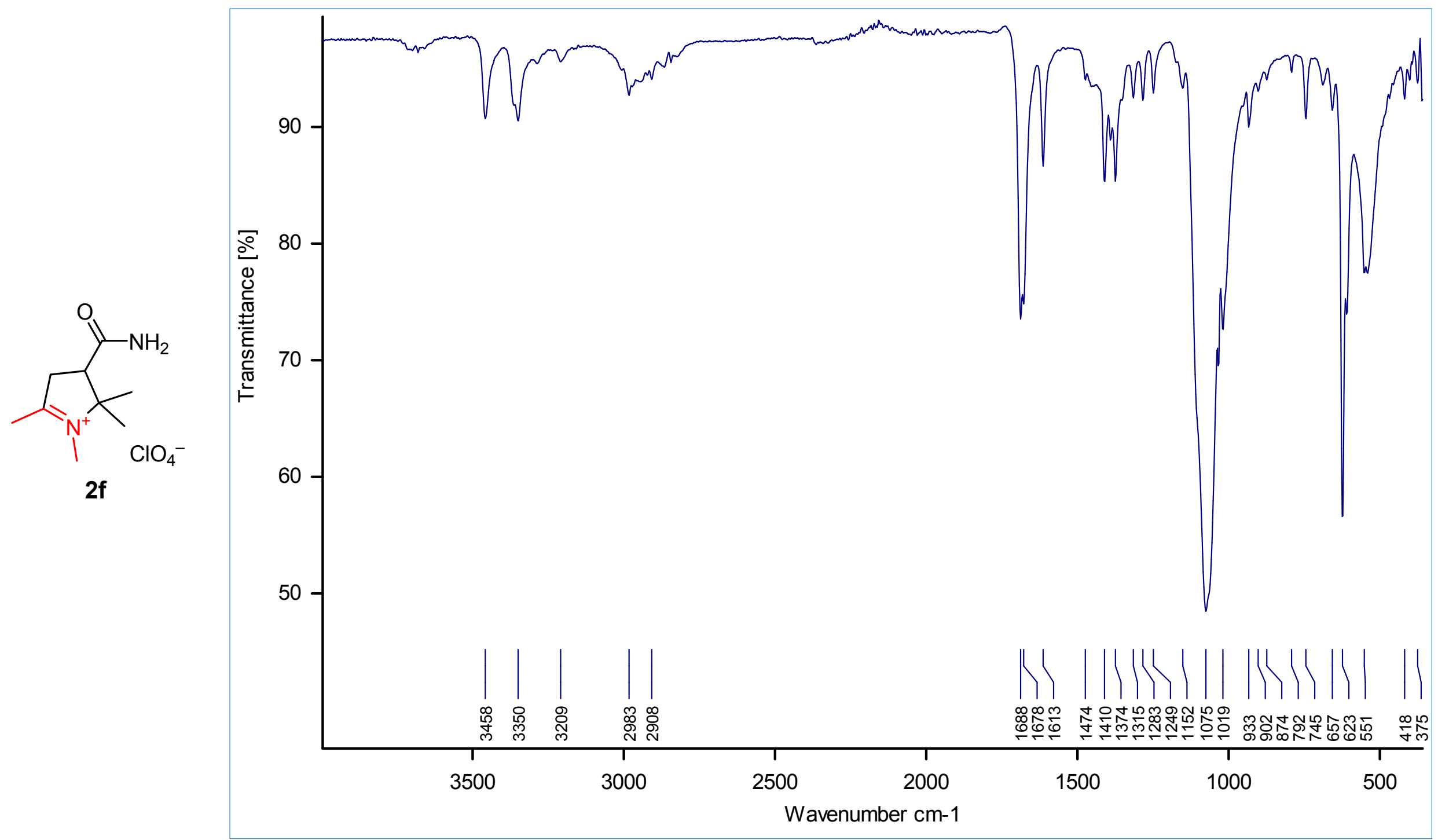

Figure S2.3. IR spectrum of iminium salt 2c. 


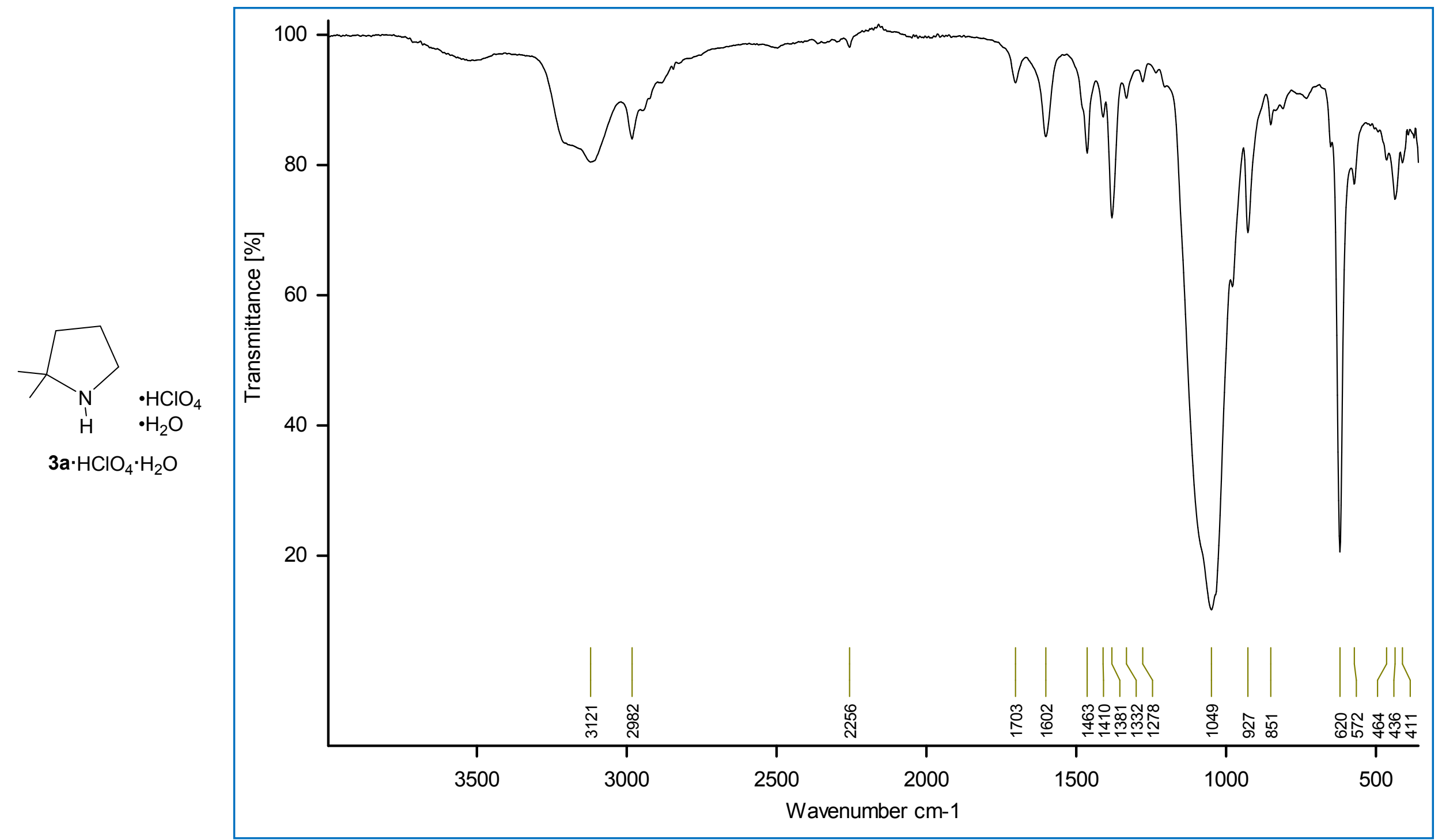

Figure S2.4. IR spectrum of pyrrolidinium salt $\mathbf{3 a} \cdot \mathrm{HClO}_{4} \cdot \mathrm{H}_{2} \mathrm{O}$. 


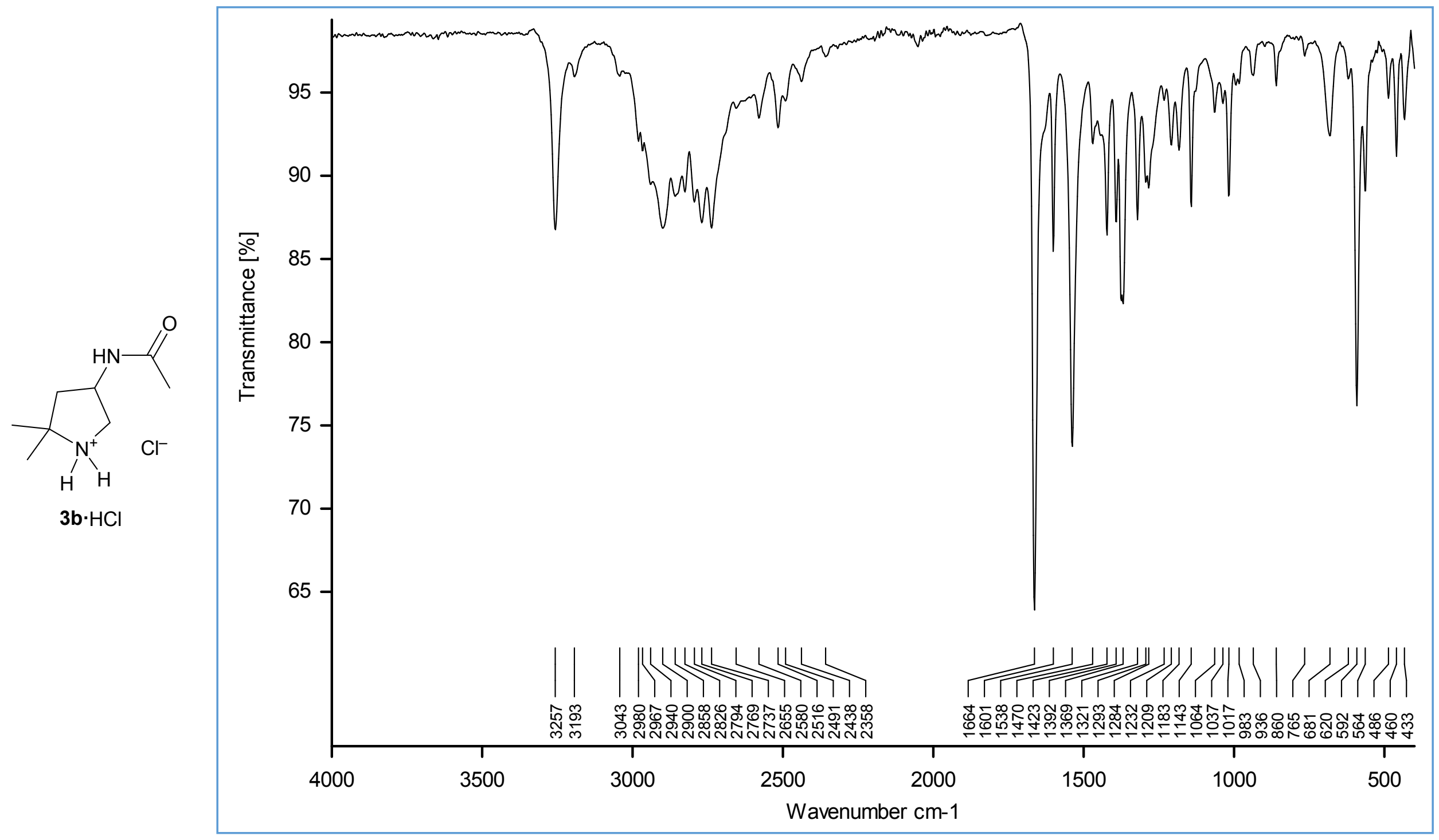

Figure S2.5. IR spectrum of pyrrolidinium salt $\mathbf{3 b} \cdot \mathrm{HCl}$. 


\section{Mass spectra}

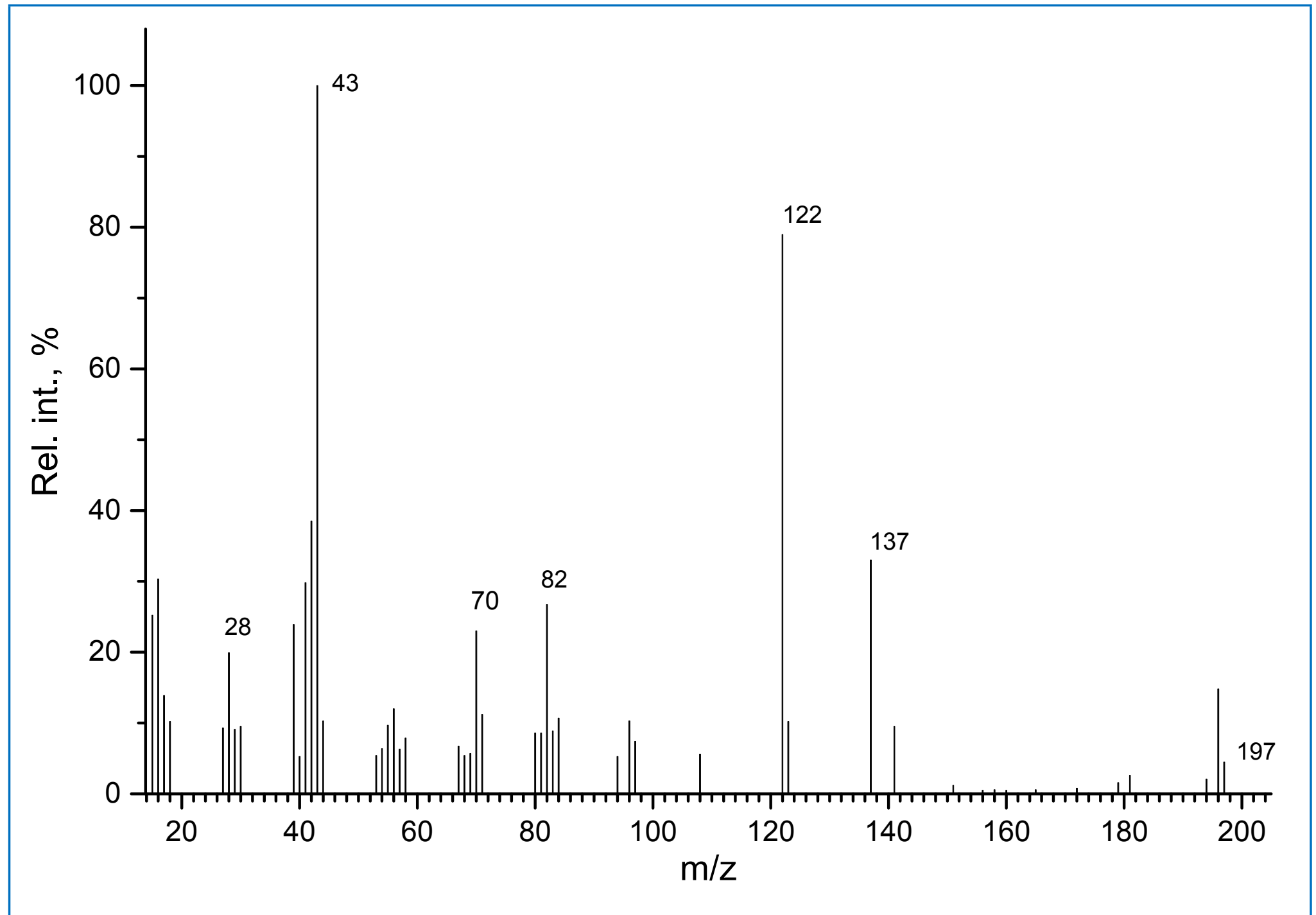

Figure S3.1. Mass spectrum of iminium salt $\mathbf{2 b}$. 

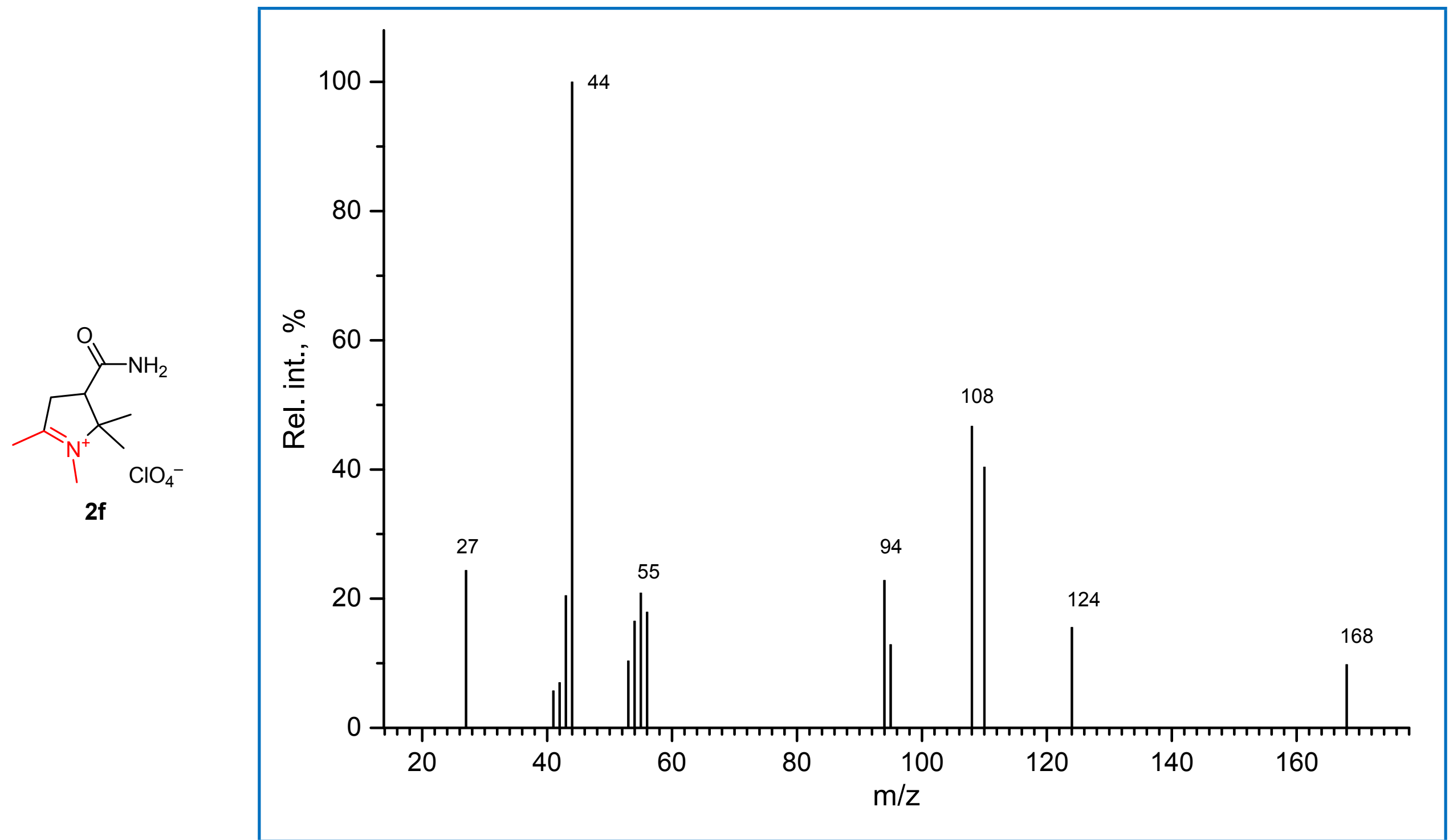

Figure S3.2. Mass spectrum of iminium salt 2f. 


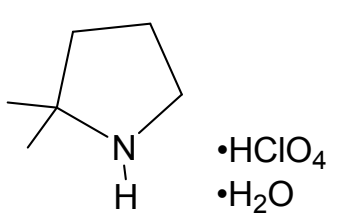

$3 \mathrm{a} \cdot \mathrm{HClO}_{4} \cdot \mathrm{H}_{2} \mathrm{O}$

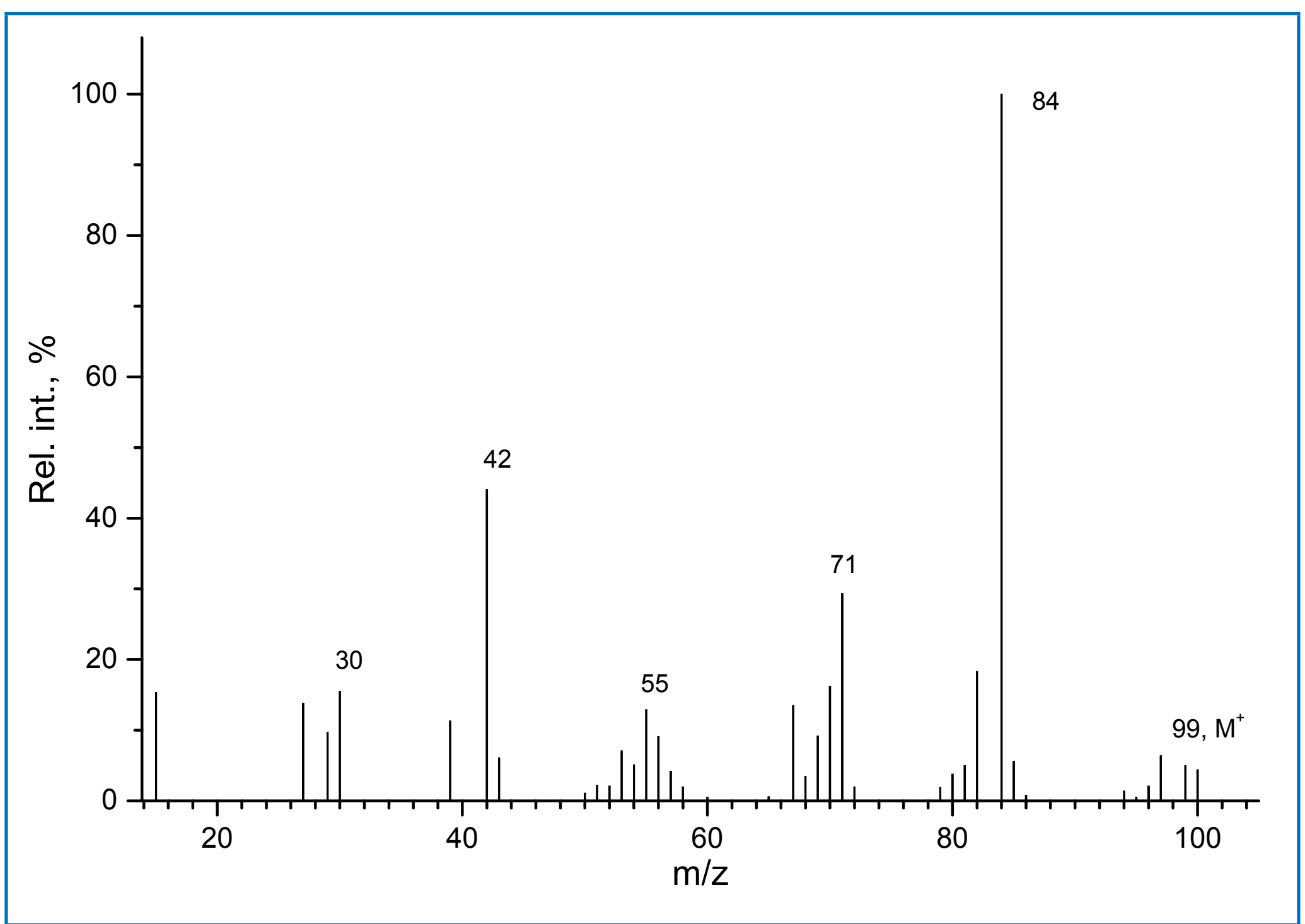

Figure S3.3. Mass spectrum of pyrrolidinium salt $\mathbf{3 a} \cdot \mathrm{HClO}_{4} \cdot \mathrm{H}_{2} \mathrm{O}$. 


\section{X-ray crystal data}

Single crystals were grown by vapour diffusion of ether into $\mathrm{MeCN}$ solutions of $\mathbf{1 f}$ and $\mathbf{2 f}$. X-ray analysis was performed on a CCD diffractometer Agilent X Calibur with EOS detector. The data collection, processing, determination and refining of the unit cell parameters were performed using the program CrysAlis PRO (Agilent Technologies UK Ltd, Yarnton, Oxfordshire, England). The structures of compounds were solved by direct method. The positions and temperature parameters of nonhydrogen atoms were refined in the isotropic and then in the anisotropic approximation by the full-matrix least squares method. All hydrogen atoms were revealed from the difference Fourier synthesis and refined in the riding model. Selected crystallographic parameters and the data collection and refinement statistics are given in Table S4.1.

Table S4.1. X-ray diffraction collection data and refinement details for compounds $\mathbf{1 f}$ and $\mathbf{2 f}$.

\begin{tabular}{|c|c|c|}
\hline Compound & 1f & $2 f$ \\
\hline Empirical formula & $\mathrm{C}_{9} \mathrm{H}_{17} \mathrm{ClN}_{2} \mathrm{O}_{6}$ & $\mathrm{C}_{9} \mathrm{H}_{17} \mathrm{ClN}_{2} \mathrm{O}_{5}$ \\
\hline Formula weight & 284.69 & 268.69 \\
\hline Temperature / K & $100(1)$ & $100(1)$ \\
\hline Wavelength / $\AA$ & 0.71073 & 0.71073 \\
\hline Crystal system & Monoclinic & Triclinic \\
\hline Space group & $\mathrm{P} 2(1) / \mathrm{n}$ & $\mathrm{P}-1$ \\
\hline \multicolumn{3}{|l|}{ Unit cell dimensions: } \\
\hline$a / \AA$ & $9.2678(3)$ & $5.9694(5)$ \\
\hline$b / \AA$ & $12.6197(5)$ & $9.7456(7)$ \\
\hline$c / \AA$ & $11.5146(6)$ & $11.0755(8)$ \\
\hline$\alpha /^{\mathrm{o}}$ & 90 & $79.980(6)$ \\
\hline$\beta /^{\mathrm{o}}$ & $103.894(4)$ & $85.345(6)$ \\
\hline$\gamma /{ }^{o}$ & 90 & $74.130(7)$ \\
\hline Volume / $\AA^{3}$ & $1307.30(10)$ & $609.93(8)$ \\
\hline Calculated density $/ \mathrm{g} \cdot \mathrm{cm}^{-3}$ & 1.446 & 1.463 \\
\hline$Z$ & 4 & 2 \\
\hline Absorption coefficient $/ \mathrm{mm}^{-1}$ & 0.314 & 0.326 \\
\hline $\mathrm{F}(000)$ & 600 & 284 \\
\hline Crystal size / mm & $0.20 \times 0.10 \times 0.05$ & $0.23 \times 0.16 \times 0.07$ \\
\hline Theta range for data collection $/{ }^{\circ}$ & 2.704 to 29.07 & 2.704 to 29.07 \\
\hline Reflections collected / unique & 32924 / 6102 & $5098 / 3253$ \\
\hline$R_{\text {int }}$ & 0.1013 & 0.0306 \\
\hline Completeness to $\Theta=29.07 / \%$ & 99.8 & 99.7 \\
\hline Refinement method & $\begin{array}{l}\text { Full-matrix least-squares on } \\
F^{2}\end{array}$ & $\begin{array}{l}\text { Full-matrix least-squares on } \\
F^{2}\end{array}$ \\
\hline Data / restraints / parameters & $3511 / 0 / 163$ & $3253 / 0 / 154$ \\
\hline Goodness-of-fit on $F^{2}$ & 1.038 & 1.072 \\
\hline Final $R$ indices $[I>2 \operatorname{sigma}(I)]$ & $R_{1}=0.0377, w R_{2}=0.0969$ & $R_{1}=0.0557, w R_{2}=0.1274$ \\
\hline$R$ indices (all data) & $R_{1}=0.0505, w R_{2}=0.1019$ & $R_{1}=0.0866, w R_{2}=0.1405$ \\
\hline Largest diff. peak and hole / e. $\AA^{-3}$ & 0.392 and -0.381 & 0.534 and -0.503 \\
\hline
\end{tabular}




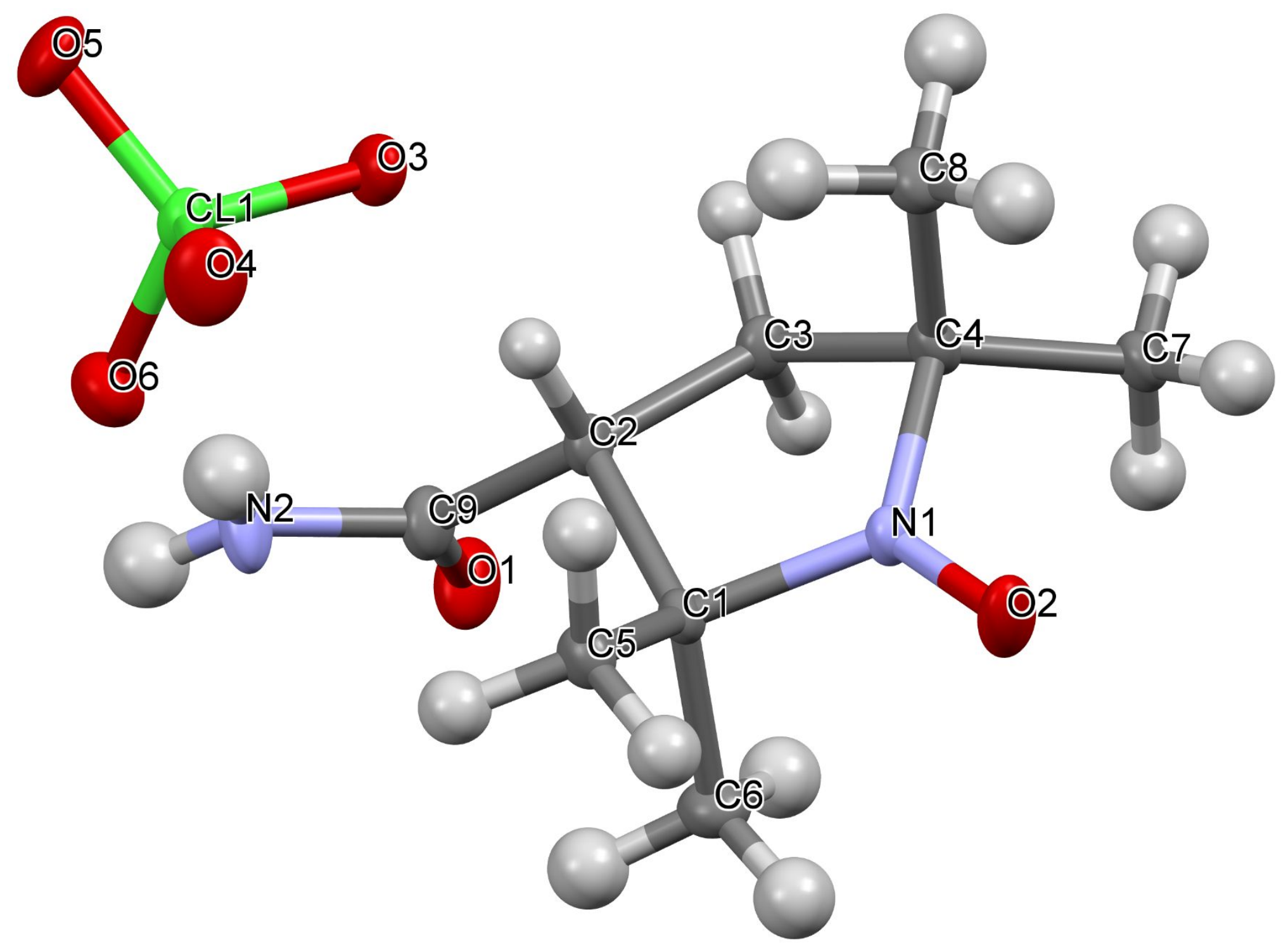

Figure S4.1. Solid-state molecular structure of oxoammonium salt 1f, with thermal ellipsoids at 50\%. 


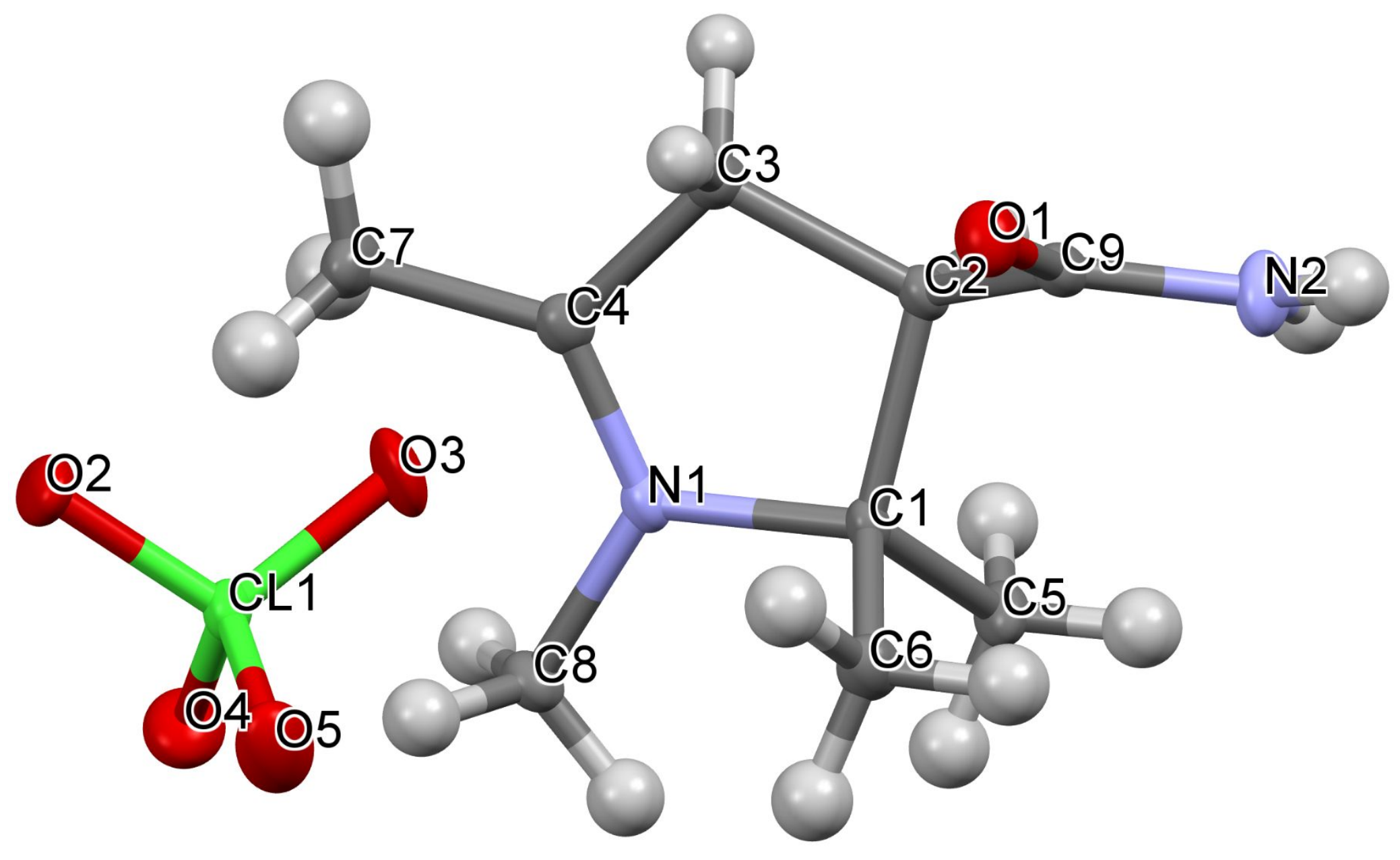

Figure S4.2. Solid-state molecular structure of iminium salt $\mathbf{2 f}$, with thermal ellipsoids at $50 \%$. 


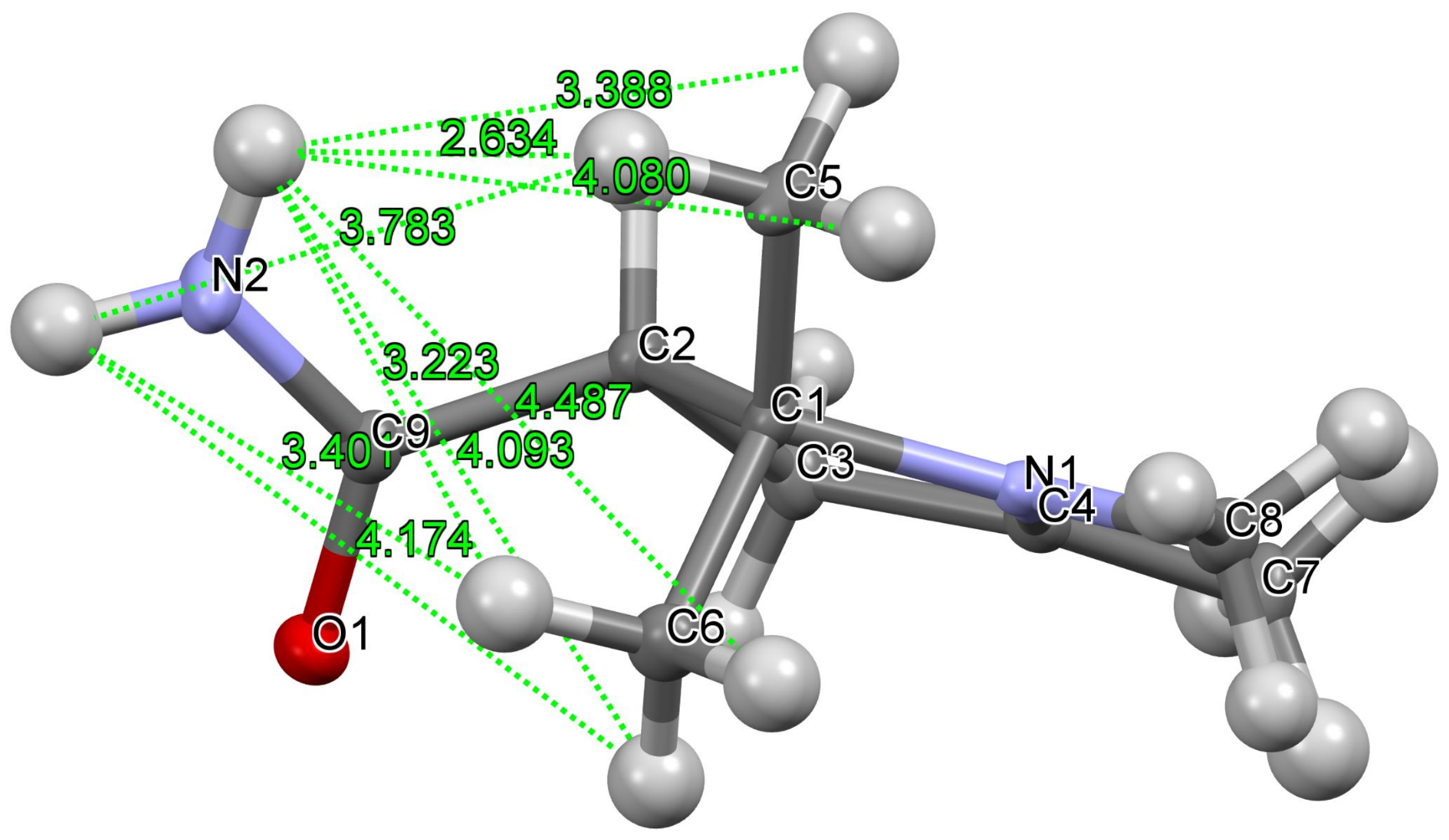

Figure S4.3. Distances $(\AA)$ between protons with spatial interactions observed in the NOESY spectrum of cation $2 \mathbf{f}$. 


\section{Charge transfer complex (ion pair) for chloride $1 \mathbf{a}^{+} \mathrm{Cl}^{-}$.}

The electronic spectra of salts $1 \mathbf{a}^{+} \mathrm{Cl}^{-}$and $\mathbf{1 \mathbf { a } ^ { + }} \mathrm{ClO}_{4}{ }^{-}$in aqueous solutions at concentrations $\leq 5 \cdot 10^{-2} \mathrm{M}$ in the range of 200-800 nm are completely identical and contain two broad absorption bands at 244 and $476 \mathrm{~nm}$, due to the absorption of hydrated cation $\mathbf{1} \mathbf{a}^{+}$.
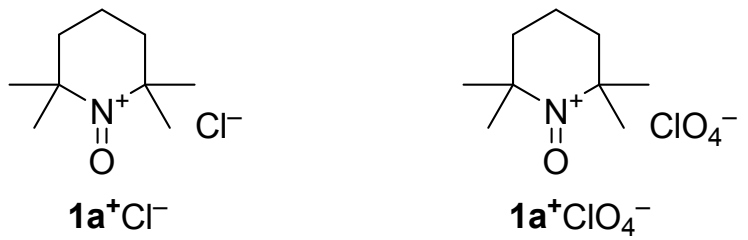

In $\mathrm{MeCN}$, the spectrum of perchlorate $\mathbf{1 a}^{+} \mathrm{ClO}_{4}^{-}$is very close to that in water ${ }^{1}$ (Figure S5.1).

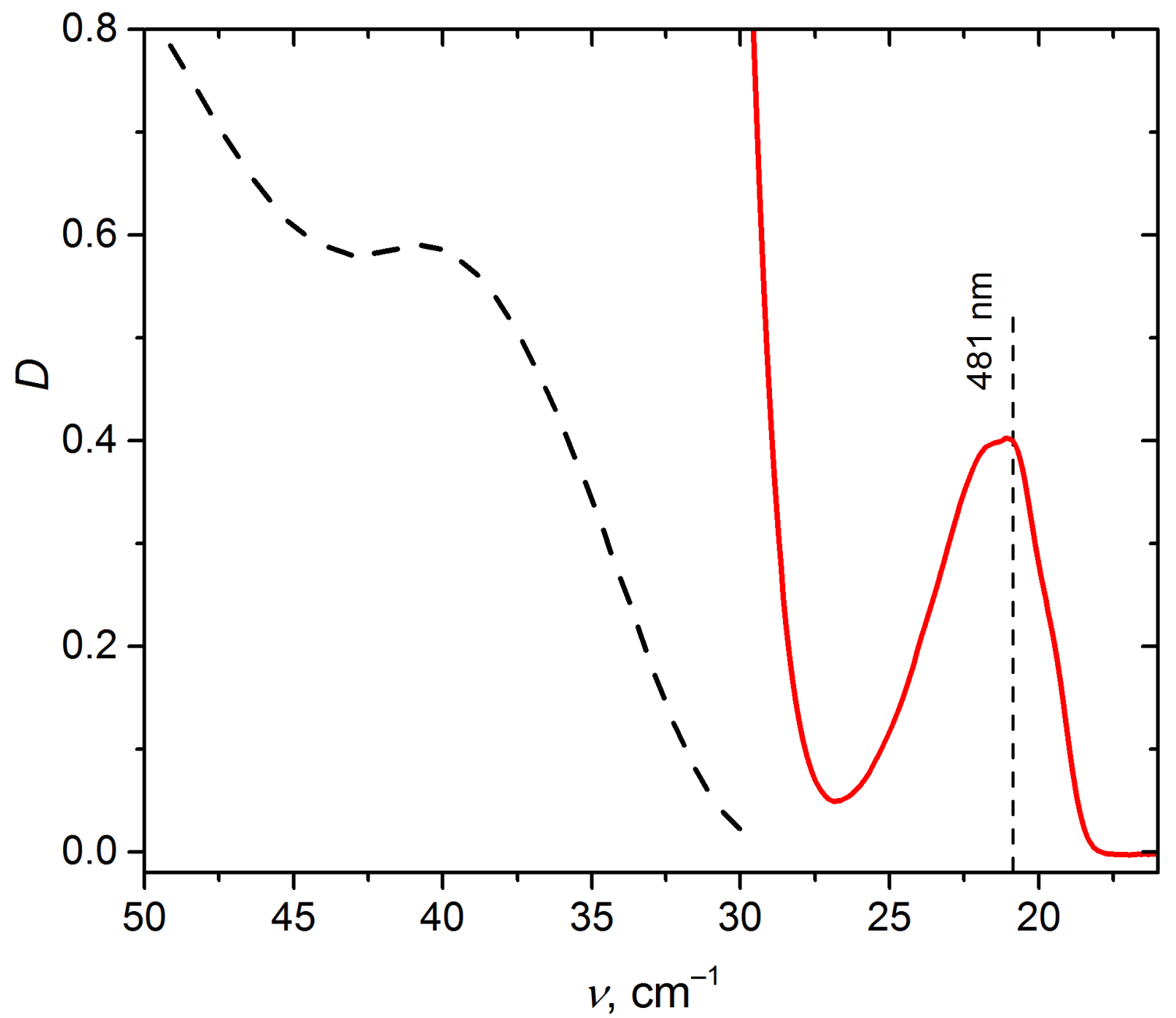

Figure S5.1. Absorption spectrum of salt $\mathbf{1 a}^{+} \mathrm{ClO}_{4}^{-}$in UV (----, $3.43 \cdot 10^{-4} \mathrm{M}, 1 \mathrm{~cm}$ cell) and in VIS range $\left(-, 9.4 \cdot 10^{-3} \mathrm{M}, 2 \mathrm{~cm}\right.$ cell $)$ in $\mathrm{MeCN}$.

The spectrum of chloride $1 \mathbf{a}^{+} \mathrm{Cl}^{-}$has a higher optical density, and the maximum of its long-wave band is shifted to $460 \mathrm{~nm}$. Unlike perchlorate $\mathbf{1 a}^{+} \mathrm{ClO}_{4}^{-}$(Figure S5.2, line 2), the optical density of this band with increasing concentration does not grow linearly, but exponentially (Figure S5.2, curve 1). ${ }^{2}$ 


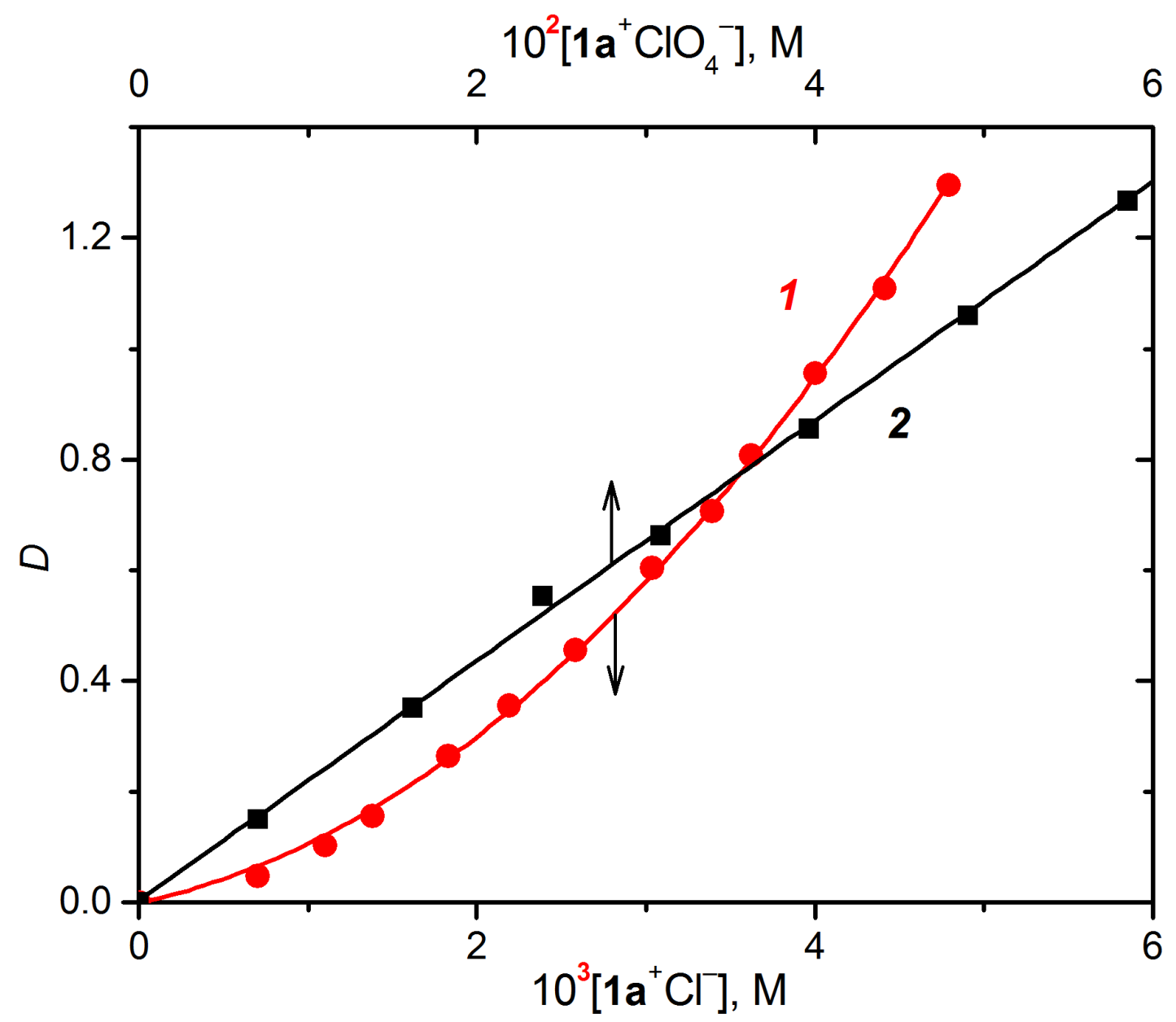

Figure S5.2. Dependence of optical density $D$ on the concentration of $\mathbf{1 a}^{+} \mathrm{Cl}^{-}(1)$ and $\mathbf{1 a} \mathbf{C}^{+} \mathrm{ClO}_{4}^{-}$(2) in $\mathrm{MeCN}$ at $\lambda 470 \mathrm{~nm}$ and a temperature of $25^{\circ} \mathrm{C}$.

At a low concentration of $\mathbf{1 a}^{+} \mathrm{Cl}^{-}$, the molar extinction coefficient of this band tends to be close to the corresponding value for $\mathbf{1 a}^{+} \mathrm{ClO}_{4}^{-}$. This indicates the presence of an equilibrium between the solvated ions and the charge transfer complex $>\mathrm{N}^{+}=\mathrm{O}^{\cdots} \mathrm{Cl}^{-}$and apparently cannot be associated with any other reaction.

$$
\mathrm{N}^{+}=\mathrm{O}+\mathrm{Cl}^{-} \stackrel{\mathrm{K}_{\mathrm{a}}}{\gtrless} \mathrm{N}^{+}=\mathrm{O} \cdots \mathrm{Cl}^{-}
$$

For equal concentrations $\left[\left[\mathbf{1 a}^{+}\right]=\left[\mathrm{Cl}^{-}\right]\right.$, the association constant is determined by relation:

$$
K_{\mathrm{a}}=\left[>\mathrm{N}^{+}=\mathrm{O} \cdots \mathrm{Cl}^{-}\right] /\left[\mathbf{1}^{+}\right]^{2}=\left(\left[\mathbf{1 a}^{+} \mathrm{Cl}^{-}\right]_{\mathrm{i}}-\left[\mathbf{1} \mathbf{a}^{+}\right]\right) /\left[\mathbf{1 a}^{+}\right]^{2}
$$

The optical density of a $1 \mathrm{~cm}$ layer of a solution $D_{\mathrm{i}}$ at a concentration $\left[\mathbf{1 a}^{+} \mathrm{Cl}^{-}\right]_{\mathrm{i}}$ for $1 \mathbf{a}^{+} \mathrm{Cl}^{-}$in $\mathrm{MeCN}$ is:

$$
D_{\mathrm{i}}=\varepsilon_{1} \cdot\left[\mathbf{1}^{+} \mathrm{Cl}^{-}\right]_{\mathrm{i}}-\varepsilon_{1}\left[\mathbf{1}^{+}\right]+\varepsilon_{2}\left[\mathbf{1} \mathbf{a}^{+}\right],
$$

where $\varepsilon_{1}$ and $\varepsilon_{2}$ are the extinction coefficients of complex $>\mathrm{N}^{+}=\mathrm{O}^{\cdots} \mathrm{Cl}^{-}$and cation $\mathbf{1 a}^{+}$. For $1 \mathbf{a}^{+} \mathrm{ClO}_{4}^{-}$, which does not form complex $>\mathrm{N}^{+}=\mathrm{O} \cdots \mathrm{Cl}^{-}$, the value of $\varepsilon_{2}$ at $470 \mathrm{~nm}$ is $21.2 \pm 0.2 \mathrm{M}^{-1} \mathrm{~cm}^{-1}$. Combining the expressions for $K_{\mathrm{a}}$ and $D_{\mathrm{i}}$, we obtain:

$$
K_{\mathrm{a}}=\left(D_{\mathrm{i}}-\varepsilon_{2} C_{\mathrm{i}}\right)\left(\varepsilon_{1}-\varepsilon_{2}\right) /\left(\varepsilon_{1} C_{\mathrm{i}}-D_{\mathrm{i}}\right)^{2}
$$

From the optical densities $D_{\mathrm{i}}$ for two different concentrations $\left[\mathbf{1 a}^{+} \mathrm{Cl}^{-}\right]_{\mathrm{i}}$ we find that $\varepsilon_{1}=1110 \pm 50 \mathrm{M}^{-1} \mathrm{~cm}^{-1}$ and $K_{\mathrm{a}}=75 \pm 3 \mathrm{M}^{-1}$ (Table S5.1). 
Table S5.1. The extinction coefficient of the charge transfer complex $>\mathrm{N}^{+}=\mathrm{O}^{\cdots} \mathrm{Cl}^{-}$and the association constant $K_{\mathrm{a}}$ for salt $1 \mathrm{a}^{+} \mathrm{Cl}^{-}$in $\mathrm{MeCN}$ at $\sim 20{ }^{\circ} \mathrm{C}$

\begin{tabular}{llll}
\hline $10^{3 \cdot\left[1 \mathbf{a}^{+} \mathrm{Cl}^{-}\right]_{\mathrm{i}}, \mathrm{M}}$ & $D_{\mathrm{i}}$ & $\varepsilon_{1}, \mathrm{M}^{-1} \mathrm{~cm}^{-1}$ & $K_{\mathrm{a}}, \mathrm{M}^{-1}$ \\
\hline 2.30 & 0.36 & - & 72 \\
2.98 & 0.59 & 1080 & 74 \\
4.03 & 0.97 & 1090 & 78 \\
4.80 & 1.28 & 1170 & 77 \\
\cline { 3 - 4 } & & $1110 \pm 50$ & $75 \pm 3$ \\
\hline
\end{tabular}

\section{References}

1. Sen', V. D.; Golubev, V. A., Kinetics and mechanism for acid-catalyzed disproportionation of 2, 2, 6, 6-tetramethylpiperidine-1-oxyl. J. Phys. Org. Chem. 2009, 22 (2), 138-143.

2. Sen', V. D. Redox reactions of di-tert-alkyl nitroxyl radicals. Ph.D. Dissertation, Institute of Organic Chemistry, Russian Academy of Sciences, Moscow, 1977. 